\title{
Fleksibilitas dan Improvisasi dalam Struktur Cak-ing Pakeliran Lakon Kalimasada Versi Ki Timbul Hadiprayitno
}

\author{
Bayu Aji Nugroho \\ Jurusan Pedalangan, Fakultas Seni Pertunjukan, Institut Seni Indonesia Yogyakarta \\ Email: astafahurjihaddika@gmail.com
}

\begin{abstract}
This paper aims to track cak-ing pakeliran of the Ki Timbul Hadiprayitno version of Lakon Kalimasada. The tracking was used to see Ki Timbul Hadiprayitno's openness towards today's development of cak-ing pakeliran. In other words, this paper aims to trace the flexibility of Ki Timbul Hadiprayitno's attitude as a puppeteer who was in jaman kelakoné. The concept of cak-ing pakeliran Mudjanattistomo et al. (1977) used as a theoretical basis. From the results of the analysis of the cak-ing pakeliran in the Lakon Kalimasada, it was found that the conclusion of Ki Timbul Hadiprayitno gave its own color in the pack of Yogyakarta style pakeliran. He followed the development of the era without damaging the existing cak-ing rules of the Yogyakarta style Pakeliran. It can be said of Ki Timbul Hadiprayitno, who was known as the mastermind who firmly maintained the Yogyakarta style puppetry, it turned out that in his career development was open to changes and developments.
\end{abstract}

Keywords: cak-ing pakeliran; lakon Kalimasada; Ki Timbul Hadiprayitno; flexible

\begin{abstract}
Abstrak
Tulisan ini bertujuan melacak cak-ing pakeliran Lakon Kalimasada versi Ki Timbul Hadiprayitno. Pelacakan tersebut digunakan untuk melihat keterbukaan Ki Timbul Hadiprayitno terhadap perkembangan cak-ing pakeliran jaman ini. Dengan kata lain tulisan ini bertujuan melacak kelenturan sikap Ki Timbul Hadiprayitno sebagai seorang dalang yang anut jaman kelakoné. Konsep struktur cak-ing pakeliran Mudjanattistomo dkk. (1977) digunakan sebagai landasan teori. Dari hasil analisis terhadap cak-ing pakeliran Lakon Kalimasada didapatkan kesimpulan Ki Timbul Hadiprayitno memberikan warna tersendiri dalam kemasan pakeliran gaya Yogyakarta. Ia mengikuti perkembangan jaman tanpa merusak kaidah caking pakeliran gaya Yogyakarta yang sudah ada. Dapat dikatakan Ki Timbul Hadiprayitno, yang dikenal sebagai dalang yang teguh mempertahankan pedalangan gaya Yogyakarta, ternyata dalam perkembangan kariernya terbuka terhadap perubahan dan perkembangan jaman.
\end{abstract}

Kata kunci: cak-ing pakeliran; lakon Kalimasada; Ki Timbul Hadiprayitno; fleksibel 


\section{Pendahuluan}

KiTimbul Hadiprayitno dikenal sebagai dalang yang setia memegang teguh tradisi pedalangan gaya Yogyakarta (Tim Penulis Senawangi, 1999: 1342). Fenomena inilah yang menimbulkan ketertarikan untuk lebih dalam melihat dan mengamati hasil pergelarannya baik yang dipentaskan langsung maupun yang telah direkam dalam bentuk rekaman audio. Salah satu yang dapat dilihat dari hasil pergelarannya dalam kaitannya dengan pernyataan sebagai dalang tradisi gaya Yogyakarta adalah struktur caking pakelirannya.

Pergelaran Ki Timbul Hadiprayitno dalam bentuk rekaman audio masih sering diputar ulang oleh banyak stasiun radio swasta di Yogyakarta. Berdasarkan pengamatan terdapat lima lakon yang sering diputar ulang di stasiun-stasiun radio tersebut, ialah Lakon Kalimasada, Lakon Imandaya Nutuh, Lakon Kuncaramanik, Lakon Setya Wening, dan Lakon Sembadra Ratu.

Berdasarkan pengamatan dari kelima lakon tersebut, Lakon Kalimasada memiliki struktur caking pakeliran yang unik. Dikatakan unik karena banyak unsur-unsur caking pakeliran jika dilihat dari struktur caking pakeliran gaya Yogyakarta versi Mudjanattistomo dkk. (1977) terdapat penambahan, pengurangan, dan penggantian.

Dikatakan oleh Mudjanattistomo dkk. (1977: 161-167) bahwa ada empat unsur di dalam struktur caking pakeliran, yaitu unsur pengadegan yang terdiri dari adegan jejer, adegan gladhagan, dan adegan tambahan. Unsur iringan terdiri dari iringan gending, sulukan, keprakan, dan dhodhogan. Unsur naratif terdiri dari janturan, kandha, carita, dan pocapan. Unsur gerak yaitu sabetan yang terdiri dari wayang mlebu (wayang hadir di kelir), tanceban (teknik penancapan tokoh boneka wayang pada batang pisang dan penataannya di kelir), solah (berbagai ragam gerak wayang di kelir), kéntas (wayang meninggalkan kelir), dan lainnya sesuai kebutuh an gerak dalam rangka menghidupkan wayang dengan ragam gerakan ketika sudah berada pada kelir. Berdasarkan konsep struktur caking pakeliran Mudjanattistomo dkk. (1977) tersebut, telah dilakukan pelacakan unsur-unsur caking pakeliran Lakon Kalimasada versi Ki Timbul Hadiprayitno. Dari hasil pelacakan tersebut ada beberapa hal yang dapat dicatat, yaitu adanya penambahan, pengurangan, dan penggantian yang terjadi pada struktur pengadegan, unsur iringan, dan unsur naratif.

Berikut merupakan hasil pelacakan lebih dalam terhadap penambahan, pengurangan, dan penggantian unsur-unsur caking pakeliran Lakon Kalimasada versi Ki Timbul Hadiprayitno.

\section{Penambahan dan Pengurangan dalam Unsur Pengadegan Lakon Kalimasada Versi Ki Timbul Hadiprayitno}

Berdasarkan pelacakan terhadap struktur caking pakeliran Lakon Kalimasada dapat dikatakan terdapat penambahan dan pengurangan unsurunsur caking pakeliran yang dilakukan oleh Ki Timbul Hadiprayitno. Pertama-tama akan dibahas penambahan dan pengurangan yang terjadi pada unsur pengadegan. Pengurangan adegan jejer dan adanya adegan tambahan disebabkan oleh munculnya peristiwa-peristiwa yang terjadi sesuai dengan jalannya cerita.

Lakon Kalimasada memiliki empat adegan jejer, yaitu: adegan jejer I, jejer II, jejer IV, dan jejer V, tanpa adanya adegan jejer III, jejer VI, dan jejer VII. Penambahan dan pengurangan unsur pengadegan dalam Lakon Kalimasada dapat dilihat pada tabel 1a dan tabel 1b. Agar penambahan dan pengurangan tersebut tampak jelas di sini akan ditampilkan bersama dengan lakon-lakon yang juga mengalami penambahan dan pengurangan pada unsur pengadegan.

Tabel 1a. Pembagian unsur pengadegan Lakon Kalimasada dengan keempat lakon lainnya pada wilayah pathet nem.

\begin{tabular}{|c|c|c|c|c|c|c|c|c|c|}
\hline \multirow{3}{*}{ Lakon } & \multicolumn{9}{|c|}{ Wilayah Pathet Nem } \\
\hline & \multicolumn{6}{|c|}{ Jejer I } & \multirow{2}{*}{$\begin{array}{c}\text { Jejer II } \\
\text { Adegan } \\
\text { Perang } \\
\text { Simpangan }\end{array}$} & \multicolumn{2}{|c|}{ Jejer III } \\
\hline & $\begin{array}{c}\text { Adegan } \\
\text { Pasowan } \\
\text { Agung }\end{array}$ & $\begin{array}{c}\text { Adegan } \\
\text { Kondur } \\
\text { Ngedhaton }\end{array}$ & $\begin{array}{c}\text { Adegan } \\
\text { Paséban } \\
\text { nJawi }\end{array}$ & $\begin{array}{c}\text { Adegan } \\
\text { Perang } \\
\text { Kembang }\end{array}$ & $\begin{array}{c}\text { Adegan } \\
\text { Perang } \\
\text { Ampyak }\end{array}$ & $\begin{array}{c}\text { Adegan } \\
\text { Jejer }\end{array}$ & & $\begin{array}{c}\text { Adegan } \\
\text { Jejer }\end{array}$ & $\begin{array}{c}\text { Adegan } \\
\text { Perang } \\
\text { Gagal }\end{array}$ \\
\hline Kalimasada & $\sqrt{ }$ & limbukan & $\sqrt{ }$ & $\sqrt{ }$ & - & $\sqrt{ }$ & $\sqrt{ }$ & gladhagan & - \\
\hline Imandaya Nutuh & $\sqrt{ }$ & - & $\sqrt{ }$ & $\sqrt{ }$ & - & $\sqrt{ }$ & $\sqrt{ }$ & gladhagan & - \\
\hline Kuncaramanik & $\sqrt{ }$ & - & $\sqrt{ }$ & $\sqrt{ }$ & - & $\sqrt{ }$ & $\sqrt{ }$ & - & - \\
\hline Setya Wening & $\sqrt{ }$ & $\sqrt{ }$ & - & $\sqrt{ }$ & - & $\sqrt{ }$ & $\sqrt{ }$ & gladhagan & - \\
\hline Sembadra Ratu & $\sqrt{ }$ & - & $\sqrt{ }$ & $\sqrt{ }$ & - & $\sqrt{ }$ & $\sqrt{ }$ & gladhagan & - \\
\hline
\end{tabular}


Tabel 1b. Pembagian unsur pengadegan Lakon Kalimasada dengan keempat lakon lainnya pada wilayah pathet sanga dan pathet manyura.

\begin{tabular}{|c|c|c|c|c|c|c|c|c|c|c|}
\hline \multirow{3}{*}{ Lakon } & \multicolumn{5}{|c|}{ Wilayah Pathet Sanga } & \multicolumn{5}{|c|}{ Wilayah Patbet Manyura } \\
\hline & \multirow[b]{2}{*}{$\begin{array}{c}\text { Adegan } \\
\text { Gara- } \\
\text { gara }\end{array}$} & \multicolumn{2}{|c|}{ Jejer IV } & \multicolumn{2}{|c|}{ Jejer V } & \multicolumn{2}{|c|}{ Jejer VI } & \multicolumn{3}{|c|}{ Jejer VII } \\
\hline & & $\begin{array}{c}\text { Adegan } \\
\text { Jejer }\end{array}$ & $\begin{array}{c}\text { Adegan } \\
\text { Perang } \\
\text { Bégal }\end{array}$ & $\begin{array}{c}\text { Adegan } \\
\text { Jejer }\end{array}$ & $\begin{array}{c}\text { Adegan } \\
\text { Perang } \\
\text { Tanggung }\end{array}$ & $\begin{array}{l}\text { Adegan } \\
\text { Jejer }\end{array}$ & $\begin{array}{c}\text { Adegan } \\
\text { Perang } \\
\text { Tandang }\end{array}$ & $\begin{array}{c}\text { Adegan } \\
\text { Jejer }\end{array}$ & $\begin{array}{l}\text { Adegan } \\
\text { Perang } \\
\text { Brubub }\end{array}$ & $\begin{array}{c}\text { Adegan } \\
\text { Pung- } \\
\text { kasan }\end{array}$ \\
\hline Kalimasada & $\sqrt{ }$ & $\sqrt{ }$ & $\sqrt{ }$ & $\sqrt{ }$ & $\sqrt{ }$ & gladhagan & - & gladhagan & - & $\sqrt{ }$ \\
\hline Imandaya Nutuh & $\sqrt{ }$ & $\sqrt{ }$ & $\sqrt{ }$ & $\sqrt{ }$ & $\sqrt{ }$ & gladhagan & - & gladhagan & - & $\sqrt{ }$ \\
\hline Kuncaramanik & $\sqrt{ }$ & $\sqrt{ }$ & $\sqrt{ }$ & $\sqrt{ }$ & $\sqrt{ }$ & gladhagan & - & gladhagan & - & $\sqrt{ }$ \\
\hline Setya Wening & $\sqrt{ }$ & $\sqrt{ }$ & $\sqrt{ }$ & $\sqrt{ }$ & $\sqrt{ }$ & gladhagan & - & gladhagan & - & $\sqrt{ }$ \\
\hline Sembadra Ratu & $\sqrt{ }$ & $\sqrt{ }$ & $\sqrt{ }$ & $\sqrt{ }$ & $\sqrt{ }$ & gladhagan & - & gladhagan & - & $\sqrt{ }$ \\
\hline
\end{tabular}

Perbedaan unsur pengadegan Lakon Kalimasada dengan keempat lakon lainnya terletak pada adegan tambahan yang muncul pada setiap jejer. Struktur pengadegan Lakon Kalimasada pada wilayah pathet nem terdapat dua adegan jejer, yaitu jejer I dan II. Jejer III pada lakon ini digantikan dengan gladhagan yang sudah memasuki wilayah pathet sanga. Persamaan adanya jejer I, jejer II, dan jejer III diganti dengan gladhagan sama dengan yang terjadi pada Lakon Imandaya Nutuh, Setya Wening, dan Lakon Sembadra Ratu.

Jejer I Lakon Kalimasada terdapat beberapa adegan diantaranya adegan Negara Ngastina, adegan paséban njawi, dan adegan perang kembang. Pada adegan kondur ngedhaton tidak ditampilkan, melainkan diganti dengan peristiwa limbukan. Selesai adegan limbukan dilanjutkan pembawaan carita yang menceritakan prosesi kondur ngedhaton Prabu Duryudana kemudian bertemu dengan permaisurinya, Dewi Banowati. Prabu Duryudana memasuki sanggar pamujan untuk bersamadi. Pada adegan paséban njawi tidak terdapat peristiwa budhalan prajurit namun dilanjutkan dengan adegan perang kembang antara pihak kerabat Negara Ngastina melawan pihak kerabat Negara Ngamarta. Dalam jejer II terdapat beberapa adegan, diantaranya adegan Kahyangan Sapta Pratala dan adegan perang simpangan. Jejer III pada Lakon Kalimasada diganti menjadi gladhagan yang terjadi di Negara Jangkarbumi.

Ada catatan penting dalam Lakon Kalimasada, yaitu pada adegan kondur ngedhaton yang diganti menjadi peristiwa limbukan. Hal ini tidak terjadi dalam lakon lain seperti Lakon Imandaya Nutuh, Lakon Kuncaramanik, Lakon Setya Wening, dan Lakon Sembadra Ratu. Hal yang sangat menarik dalam adegan limbukan adalah kejujuran dan keterbukaan Ki Timbul Hadiprayitno menyikapi kondisi jaman. Keterbukaan Ki Timbul Hadiprayitno dapat dilihat dalam pocapan antara tokoh wayang Limbuk dan Cangik. Berikut kutipan pocapan dalam limbukan Lakon Kalimasada.

Cangik : "Rasah nembang ndak kesuwèn."

Limbuk: "Iya Mak. Yahméné kok metu ta Mak?"

Cangik : "Sing dhawuh ki Pak Gino tak kandhani. Nèk saiki aku karo kowé ora metu, wooo sengeni."

Limbuk : "Jaréné nèk kowé karo aku yahméné metu ki cara Sala?"

Cangik : "Halah, jamané kaya ngéné kok mbédakké Sala karo Yoja ta Nggèr. "Sala Yoja kuwi cara wong omah-omah mung adu tritis, sumberé padha déné Mataram. Ambèka wayangan saiki sing alus ki wis ora ènèk. Yoja sing alus mulus ya wis ora ènèng, Sala sing alus ya wis ora ènèng, kabèh blorok, nèk ora gelem blorok malah ora payu, lho rak ngono ta."

Limbuk: "Oh..."

Cangik : "He'em, aku isa tekan ngendi-endi ki ya tèké blorok kuwi tak kandhani." (Hadiprayitno, Lakon Kalimasada, MP3 No.02: menit ke $36.46-37.50$ )

Terjemahan:

Cangik : "Tidak usah nyanyi nanti kelamaan."

Limbuk: "Iya Mak. Baru jam segini kita kok sudah tampil Mak?"

Cangik : "Yang menyuruh tampil itu Bapak Gino. Kalau sekarang kita tidak keluar, wooo (kita) dimarahi."

Limbuk: "Katanya kalau kita tampil saat ini disebut (pakeliran) gaya Surakarta?"

Cangik : "Halah, jamannya seperti ini kok masih membeda-bedakan Surakarta dan 
Yogyakarta, Nak. Surakarta Yogyakarta apabila diibaratkan seperti kehidupan bertetangga, teras depannya saling beradu, sumbernya sama-sama dari Mataram. Apalagi pertunjukan wayang sekarang ini yang lugu (klasik) sudah tidak ada. Gaya Yogyakarta yang masih lugu sudah tidak ada. Gaya Surakarta yang masih lugu juga tidak ada, semuanya sudah bercampur (gaya Yogyakarta dan gaya Surakarta), kalau tidak campur justru Limbuk : "Oh..." tidak laku, begitu kan?"

Cangik : "Iya, kamu tak kasih tahu, aku bisa ke mana-mana seperti ini iya karena (pementasannya) memadukan dua gaya itu"”

Melihat sepenggal pocapan pada peristiwa limbukan Lakon Kalimasada dapat dikatakan bahwa Ki Timbul Hadiprayitno tidak fanatik dalam menerapkan caking pakeliran pada pementasannya. Sesuai yang diungkapkan oleh Kasidi (wawancara, 08 Juni 2016), bahwa caking pakeliran Ki Timbul Hadiprayitno secara garis besar masih mengikuti cak-cakan gaya Yogyakarta, namun beliau juga termasuk salah satu dalang Yogyakarta yang mempopulerkan peristiwa limbukan mulai sekitar tahun 1992-an. Namun tidak semua pementasan Ki Timbul Hadiprayitno terdapat peristiwa limbukan. Peristiwa limbukan muncul di pementasan pada saat-saat tertentu melihat situasi kondisi serta memenuhi permintaan dari pihak penanggap. Kebutuhan saat peristiwa limbukan Lakon Kalimasada antara lain untuk memenuhi permintaan pihak penanggap, menyampaikan visi dan misi acara pementasan. Adapun tembang yang dibawakan oleh waranggana dan niyaga hanya bawa Tembang Pangkur laras sléndro pathet sanga dilanjutkan dengan Langgam Ngimpi laras sléndro pathet sanga. Dengan demikian dapat diartikan bahwa peristiwa limbukan tersebut tidak semacam hura-hura layaknya limbukan sekitar tahun 1995an akhir hingga tahun 2000-an.

Prosesi kondur ngedhaton hingga adegan kondur ngedhaton usai adegan jejer I sudah dikemas atau digedhong menjadi bentuk deskripsi kandha. Seharusnya adegan kondur ngedhaton yang dikelirkan berisi adegan sang raja bertemu permaisuri di depan gapura danapratapa disertai iringan gending disirep disambung pembawaan janturan, suluk lagon, dan pocapan. Namun pada Lakon Kalimasada rangkaian unsur-unsur tersebut diganti menjadi peristiwa limbukan yang cenderung menunjukkan abdi keraton Cangik dan Limbuk sedang menghibur seorang raja dan permaisurinya saat melakukan kembul bojana. Dilanjutkan pembawaan deskripsi kandha singkat yang menceritakan bahwa Prabu Duryudana telah usai kembul bojana suka parisuka didampingi Dewi Banowati. Namun isi kandha tersebut terkesan sudah mencakup rangkaian unsur-unsur yang seharusnya muncul saat adegan kondur ngedhaton.

Adegan paséban njawi pada Lakon Kalimasada tanpa ada peristiwa budhalan. Selesai adegan paséban njawi dilanjutkan dengan adegan Raden Setyaki menghadap Raden Sadewa kemudian terjadi adegan perang kembang. Adegan perang kembang terjadi antara pihak kerabat Negara Ngastina melawan pihak kerabat Negara Ngamarta. Pihak kerabat Negara Ngastina kalah. Jejer II terjadi di Kahyangan Sapta Pratala. Dalam jejer II terjadi adegan perang simpangan antara Raden Antareja sebagai pihak kerabat Kahyangan Sapta Pratala melawan Raden Gathutkaca sebagai pihak kerabat Negara Ngamarta. Keduanya sama-sama sakti dan kuat sehingga dalam peperangan itu tidak ada yang menang dan tidak ada yang kalah. Kemudian jejer III pada Lakon Kalimasada tidak muncul, melainkan diganti menjadi adegan gladhagan terjadi di Negara Jangkarbumi. Pada gladhagan tersebut tidak terdapat adegan perang.

Secara umum struktur pengadegan Lakon Kalimasada pada wilayah pathet nem sesuai dengan kaidah struktur caking pakeliran gaya Yogyakarta. Dalam lakon tersebut terdapat penambahan dan pengurangan pada unsur pengadegan namun tidak mengubah bentuk dari struktur caking pakeliran gaya Yogyakarta, di antaranya: munculnya peristiwa limbukan, adegan kondur ngedhaton yang dikemas dalam bentuk kandha, peristiwa budhalan tidak muncul pada adegan paséban njawi, peran jejer III diganti dengan adegan gladhagan. Tidak adanya jejer III juga menghilangkan adegan perang gagal.

Struktur pengadegan pada wilayah pathet sanga Lakon Kalimasada ditandai dengan gladhagan pengganti jejer III yang terjadi di Negara Jangkarbumi. Adegan gara-gara Lakon Kalimasada di dalamnya terdapat pocapan antar punakawan, 
tarian punakawan, dan tembang-tembang yang dilantunkan oleh dalang didukung oleh waranggana dan para wiyaga. Selesai adegan gara-gara lalu memasuki jejer IV. Jejer IV pada Lakon Kalimasada terjadi di Negara Ngamarta. Dalam jejer tersebut terdapat adegan perang bégal yang terjadi di tengah hutan belantara. Adegan perang bégal tersebut biasa disebut oleh masyarakat pedalangan dengan istilah cakilan, yaitu istilah perang antara tokoh ksatria bambangan melawan tokoh prajurit raksasa (cakil). Dalam wilayah pathet sanga Lakon Kalimasada tidak terdapat penambahan dan pengurangan unsur pengadegan.

Wilayah pathet manyura Lakon Kalimasada dimulai pada jejer V. Jejer VI dan jejer VII lakon tersebut diganti menjadi gladhagan. Gladhagan yang menggantikan peran jejer VI terjadi di Negara Ngamarta. Sedangkan adegan gladhagan yang menggantikan jejer VII terjadi di Kahyangan Sapta Pratala. Selain gladhagan juga terdapat adegan-adegan tambahan yang muncul sesuai kebutuhan cerita pada lakon tersebut. Adapun adegan tambahan yang muncul pada wilayah pathet manyura adalah adegan kaki Gunung Siula-ulu sebelum adegan perang tanggung, adegan Pandhita Durna dan Bathari Durga setelah adegan Kahyangan Sapta Pratala, adegan tapel wates Negara Ngamarta setelah adegan Pandhita Durna dan Bathari Durga. Setelah rangkaian peristiwa dalam adegan-adegan tambahan diakhiri adegan Negara Ngamarta sebagai adegan pungkasan. Dalam wilayah pathet manyura Lakon Kalimasada terdapat banyak adegan perang namun tidak dapat dikategorikan sebagai adegan perang tandang dan adegan perang brubuh (ageng), karena mengingat tidak adanya jejer VI dan jejer VII.

Jika dicermati lebih teliti, sebenarnya di dalam adegan-adegan tambahan terdapat peristiwaperistiwa yang saling terkait. Hal demikian dimungkinkan terjadi karena adegan-adegan yang tampil disesuaikan dengan kebutuhan cerita pada setiap lakon yang erat kaitannya dengan adegan atau bahkan jejer itu sendiri (Kasidi, 2009: 6970). Beberapa adegan-adegan tambahan tersebut diantaranya berperan menjadi gladhagan dan adegan perang. Adanya adegan-adegan tambahan pada wilayah pathet manyura Lakon Kalimasada dapat dimungkinkan karena waktu pementasan yang mendesak. Pada situasi tersebut menjadikan seorang dalang kemungkinan besar melakukan improvisasi untuk menyanggit lakon yang sedang dipentaskan di bawah bléncong, biasa disebut oleh kalangan seniman pedalangan dengan istilah "sanggit ngisor bléncong”. Selain itu suasana di sekitar lokasi pementasan biasanya juga mempengaruhi dalang untuk merangsang ide atau menampilkan hal-hal baru melalui media pakelirannya. Cara tersebut dimungkinkan terjadi agar pementasan yang disajikan tampil lebih menarik dan memikat, maka perlu adanya perubahan-perubahan berdasarkan tuntutan jaman. Sesuai dengan pendapat tersebut, Kasidi (2000: 84) juga menjelaskan lebih detail bahwa perubahan seni pertunjukan bisa terjadi berkat majunya pola pikir manusia seiring dengan modernisasi di segala bidang, perubahan jaman, globalisasi, dan teknologi informasi, dalam istilah bahasa Jawa lebih tepat dikatakan "anut jaman kelakoné". Namun demikian perubahan itu bukan berarti merombak secara total pola pertunjukan yang sudah ada, melainkan lebih mengarah pada langkah-langkah inovatif sesuai kapasitas pelaku seni atau dalang itu sendiri.

Inovasi Ki Timbul Hadiprayitno terbuka dan tertuang pada wilayah pathet nem Lakon Kalimasada saat peristiwa limbukan bahwa caking pakelirannya sudah bercampur antara gaya Yogyakarta dengan gaya Surakarta. Beliau juga mengakui yang membawa dirinya dapat mementaskan pertunjukan wayang kulit sampai di mana-mana karena percampuran gaya pada pakelirannya. Pada wilayah pathet sanga Lakon Kalimasada juga terlihat inovasi Ki Timbul Hadiprayitno pada adegan perang bégal. Untuk dapat memunculkan cakilan, beliau terkesan memberi nama tokoh buta cakil tersebut dengan spontanitas, yaitu Ditya Kala Ėnèng-ènèng Sepègsepèg Sekrup dan Ditya Kala Montrokendho.

Wilayah pathet manyura Lakon Kalimasada terdapat peristiwa perang yang terjadi sebelum adegan pungkasan. Peristiwa perang yang terjadi dalam jejer VII sebelum adegan pungkasan dinamakan adegan perang brubuh atau perang ageng. Pada Lakon Kalimasada keberadaan jejer VII tidak tampak, namun terdapat peristiwa perang terjadi sebelum adegan pungkasan. Peristiwa perang ini jika dipahami sebagai perang terakhir yang terjadi pada wilayah pathet manyura, dapat disebut sebagai adegan perang brubuh (Tim Penulis Senawangi, 2016:93-94). Perang brubuh adalah perang terakhir 
yang terjadi dalam wilayah pathet manyura di mana dalam adegan perang tersebut ditampilkan tokohtokoh pecundang yang mencapai tujuan dengan cara curang akan dikalahkan oleh tokoh utama yang biasanya para Pandhawa, khususnya Arjuna dan Bima. Adegan perang brubuh merupakan klimaks dari berbagai permasalahan dalam setiap lakon yang berisi pertentangan antara tokoh antagonis dan protagonis yang berujung pada sebuah peperangan yang menjadi pemenangnya adalah tokoh protagonis. Biasanya para tokoh protagonis pemenang perang brubuh akan atau telah berhasil mendapatkan anugerah yang diperebutkan dalam lakon misalnya: wahyu, ajian, putri, atau wilayah negara. Setelah rangkaian adegan perang tersebut selesai, diakhiri dengan adegan pungkasan sebagai tanda berakhirnya permasalahan dalam lakon tersebut (Tim Penulis Senawangi, 2016: 93-94). Pada adegan perang tersebut Werkudara berhasil mengalahkan prajurit Kurawa setelah Prabu Puntadéwa berhasil mendapatkan anugerah pusaka kahyangan Kalima Husada Pustaka Jamus, Tumbak Karawelang, dan Songsong Tunggul Naga.

Pada wilayah pathet manyura Lakon Kalimasada terdapat adegan-adegan tambahan yang muncul sesuai kebutuhan dalam lakon tersebut. Pada wilayah pathet manyura dapat dikatakan hampir seluruhnya berisi adegan. Banyaknya adegan pada wilayah pathet manyura menyerupai struktur pengadegan pada caking pakeliran gaya Surakarta. Seperti diketahui bahwa caking pakeliran wayang kulit gaya Surakarta yang utuh semalam suntuk hanya terdapat satu jejer, yaitu jejer I atau jejer pertama sedangkan lainnya berupa adegan. Sedangkan dalam wilayah pathet manyura dapat tampil tiga adegan lebih beserta peristiwa perangnya (Nojowirongko, 1954: 53).

Ki Margiyana (wawancara, 02 April 2016) yang termasuk rekan dekat sekaligus pengendhang Ki Timbul Hadiprayitno mengungkapkan bahwa
Ki Timbul memang mengidolakan seorang dalang asal Semarang yang bernama Ki Nartosabdo. Banyak sanggit lakon dan cak-cakan pakeliran $\mathrm{Ki}$ Timbul Hadiprayitno diadopsi dari karya-karya Ki Nartosabdo. Ki Timbul memiliki banyak koleksi buku pedalangan, komik, dan beberapa kaset pita rekaman audio pertunjukan wayang kulit Ki Nartosabdo. Oleh karena itu tidak mustahil jika banyak referensi yang diperoleh Ki Timbul Hadiprayitno dari koleksinya. Keniscayaan itu dapat dilihat dari model struktur pengadegan $\mathrm{Ki}$ Timbul Hadiprayitno yang dapat dikatakan hampir menyerupai struktur pengadegan Ki Nartosabdo. Pernyataan ini didapat dari mengamati rekaman audio MP3 Lakon Gathutkaca Nagih Janji versi Ki Nartosabdo.

Model struktur pengadegan Lakon Kalimasada versi Ki Timbul Hadiprayitno hampir sama dengan model struktur pengadegan Lakon Gathutkaca Nagih Janji versi Ki Nartosabdo. Persamaan struktur pengadegan kedua lakon tersebut tampak pada wilayah pathet nem dan wilayah pathet manyura. Struktur pengadegan Lakon Kalimasada versi Ki Timbul Hadiprayitno saat wilayah pathet nem masih sesuai dengan struktur caking pakeliran gaya Yogyakarta. Walaupun jika dicermati terdapat sedikit unsur pengadegan gaya Surakarta yang muncul dalam wilayah pathet nem tersebut. Struktur pengadegan Ki Timbul pada wilayah pathet manyura menyerupai struktur pengadegan gaya Surakarta. Struktur pengadegan gaya Yogyakarta yang seharusnya terdapat adegan jejer VI dan jejer VII, pada Lakon Kalimasada hanya terdapat adegan gladhagan dan beberapa adegan tambahan. Secara umum struktur pengadegan Lakon Kalimasada pada wilayah pathet manyura hampir sama dengan struktur pengadegan Lakon Gathutkaca Nagih Janji versi Ki Nartosabdo. Struktur pengadegan kedua lakon tersebut dapat dilihat pada tabel 2 .

Tabel 2. Struktur pengadegan Lakon Kalimasada versi Ki Timbul Hadiprayitno dan struktur pengadegan Lakon Gathutkaca Nagih Janji versi Ki Nartosabdo.

\begin{tabular}{cccc}
\hline & $\begin{array}{c}\text { Struktur pengadegan Lakon Kalimasada } \\
\text { versi Ki Timbul Hadiprayitno }\end{array}$ & $\begin{array}{c}\text { Struktur Pengadegan Lakon Gathutkaca Nagih Janji } \\
\text { versi Ki Nartosabdo }\end{array}$ \\
\hline No. & Keterangan & No. & Keterangan \\
\hline
\end{tabular}

1. Wilayah Pathet Nem

1.1. Jejer $\mathrm{I}$

1.1.1. Adegan Sitinggil Keraton Negara Ngastina

1.1.2. Adegan Kondur Ngedhaton (Limbukan)
1.1. Jejer

1.1.1. Adegan Sitinggil Keraton Negara Ngastina

1.1.2. Adegan Kondur Ngedhaton/Gupit Mandragini 
1.1.3. Adegan Paseban nJawi

1.1.4. Adegan Raden Setyaki menghadap Raden Sadewa

1.1.5. Adegan Perang Kembang

1.2. Jejer II

1.2.2. Adegan Raden Gathutkaca di Angkasa

1.2.3. Adegan Perang Simpangan

1.2.3. Adegan Paséban nJawi

\section{Wilayah Pathet Sanga}

2.1. Gladhagan

2.1.1. Adegan Negara Jangkarbumi

2.2. Gara-gara

2.2.1. Adegan Semar, Gareng, Petruk, dan Bagong

2.3. Jejer IV

2.3.1. Adegan Negara Ngamarta

2.3.2. Adegan Perang Bégal

3. Wilayah Pathet Manyura

3.1. Jejer $\mathrm{V}$

3.1.1. Adegan Kahyangan Jonggringsaloka

3.1.2. Adegan Kaki Gunung Siula-ulu

3.1.3. Adegan Perang Tanggung

3.2. Gladhagan

3.2.1. Adegan Negara Ngamarta

3.3. Gladhagan

3.3.1. Adegan Kahyangan Sapta Pratala

3.3.2. Adegan Pandhita Durna dan Bathari Durga

3.3.3. Adegan Tapel Wates Negara Ngamarta

3.3.4. Adegan Negara Ngamarta (Adegan Pungkasan)
1.1.3. Adegan Cangik dan Limbuk (Limbukan)

1.1.4. Adegan Paseban nJawi

1.1.5. Adegan Budhalan kapalan/jaranan lan kréta

1.2. Adegan

1.2.1. Adegan Arga Kaelasa

1.2.2. Adegan Perang Gagal

1.3. Adegan Sabrang

1.3.1. Adegan Negara Nusakambana/Nusarukmi

2.1. Gara-gara

2.2.1. Adegan Semar, Gareng, Petruk, dan Bagong

2.2.2. Adegan Perang Kembang

3.1. Adegan

3.1.1. Adegan Kahyangan Jonggringsaloka

3.2. Adegan

3.2.1. Adegan Argakaelasa

3.2.2. Adegan Perang Sampak Manyura

3.2.3. Adegan Argakaelasa

3.3. Adegan

3.3.1. Adegan Dewasrani dan Prabu Heramba

3.3.2. Adegan Perang Sampak Amuk-amukan

3.3.3. Adegan Tayungan

3.4. Adegan

3.4.1. Adegan Negara Ngamarta (Adegan Tancep Kayon)

Keterangan:

kolom tabel kosong = tidak ada adegan

\section{Penambahan dan Penggantian dalam Unsur Iringan Lakon Kalimasada versi Ki Timbul Hadiprayitno}

Mudjanattistomo dkk. (1977) menjelaskan bahwa unsur iringan pada caking pakeliran gaya Yogyakarta meliputi: iringan gending, sulukan, keprakan, dan dhodhogan. Penambahan dan penggantian unsur iringan dalam struktur caking pakeliran Lakon Kalimasada dapat dikatakan lebih dominan terlihat pada iringan gending dan sulukan. Peran iringan gending erat hubungannya dengan dhodhogan dan keprakan, sebab dhodhogan dan keprakan berperan sebagai aba-aba untuk meminta iringan gending ditabuh dan disuwuk.

Mudjanattistomo dkk. (1977: 161-166) mengatakan bahwa iringan gending dalam satu lakon yang dipentaskan hanya menggunakan laras sléndro. Namun yang terjadi di lingkungan masyarakat pedalangan iringan gending tersebut sudah mengalami pergeseran. Iringan gending dalam satu lakon yang dipentaskan menggunakan dua larasan, yaitu sléndro dan pélog. Penggunaan laras sléndro dan pélog dalam kenyataannya sama sekali tidak mengubah struktur caking pakeliran lakon yang dipentaskan.

Iringan gending pada wilayah pathet nem, awal jejer I, prosesi kondur ngedhaton, adegan paséban njawi, hingga adegan perang kembang tidak ada penambahan, pengurangan, dan penggantian iringan gending. Jejer I menggunakan iringan gending Ayak-ayak laras sléndro pathet nem dhawah menjadi Gendhing Karawitan laras sléndro pathet nem sekaligus sirep. Saat iringan Gendhing Karawitan laras sléndro pathet nem sirep, dalang membawakan janturan. Selesai pembawaan janturan, iringan Gendhing Karawitan laras sléndro pathet nem gesang. Kemudian iringan Gendhing Karawitan dhawah menjadi Ladrang Karawitan laras sléndro pathet nem hingga disuwuk antal sesuai aba-aba dhodhogan dalang. Prosesi kondur ngedhaton menggunakan iringan gending Ayak-ayak laras sléndro pathet nem dhawah menjadi Srepeg Lasem laras sléndro pathet nem disertai keprakan. Iringan gending Srepeg 
Lasem laras sléndro pathet nem diakhiri dengan munculnya tokoh Cangik dan Limbuk hingga disuwuk gropak sesuai aba-aba keprakan. Dalam peristiwa limbukan terdapat iringan gending Langgam Ngimpi laras sléndro pathet sanga yang sebelumnya diawali dengan bawa Tembang Pangkur laras sléndro sanga. Pada adegan paséban njawi menggunakan iringan gending Playon Lasem laras sléndro pathet nem disertai keprakan hingga disuwuk tanggung. Adegan perang kembang menggunakan iringan gending Playon Lasem laras sléndro pathet nem disertai keprakan.

Jejer II Lakon Kalimasada terjadi di Kahyangan Sapta Pratala. Adegan tersebut menggunakan iringan gending Gendhing Bondhèt laras pélog pathet nem. Iringan gending Gendhing Bondhèt laras pélog pathet nem disirep dilanjutkan pembawaan janturan. Selesai pembawaan janturan, kemudian iringan gending Gendhing Bondhèt laras pélog pathet nem disuwuk antal sesuai aba-aba dhodhogan. Adegan perang simpangan dalam jejer II menggunakan Iringan gending Playon Lasem laras sléndro pathet nem disertai keprakan.

Jejer III Lakon Kalimasada yang sudah diganti gladhagan terjadi di Negara Jangkarbumi. Adegan tersebut menggunakan iringan gending Playon Lasem laras sléndro pathet nem disertai keprakan. Mengingat gladhagan tersebut menjadi transisi memasuki wilayah pathet sanga, maka peristiwa yang terjadi pada gladhagan menggunakan iringan gending Playon laras sléndro pathet sanga disertai keprakan.

Adegan gara-gara Lakon Kalimasada menggunakan iringan gending Srepeg Banyumasan laras sléndro pathet sanga disertai keprakan kemudian disuwuk tanggung sesuai aba-aba keprakan. Dalam adegan gara-gara gaya Yogyakarta biasanya menggunakan iringan gending Ayak-ayak Jalumampang laras sléndro pathet sanga. Ki Timbul melakukan penggantian iringan gending pada adegan gara-gara. Penggantian iringan gending ini biasa dilakukan oleh banyak dalang sesuai tuntutan rasa masing-masing. Seperti dituturkan Udreka (wawancara, 31 Januari 2018) selaku murid Ki Timbul Hadiprayitno, bahwa setiap dalang ingin memberi sekaligus merasakan nuansa baru dengan menampilkan iringan gending yang digunakan untuk mengawali adegan gara-gara. Biasanya pada adegan gara-gara seorang dalang dapat melakukan apresiasi corak pedalangan dari daerah lain. Terbukti pada adegan gara-gara Lakon Kalimasada digunakan iringan gending gaya daerah lain, yaitu iringan gending Srepeg Banyumasan laras sléndro pathet sanga.

Memasuki adegan IV Lakon Kalimasada meng gunakan iringan gending Gendhing Gambir Sawit laras sléndro pathet sanga. Jejer IV terjadi di Negara Ngamarta. Iringan gending Gendhing Gambir Sawit laras sléndro pathet sanga disirep kemudian dalang membawakan janturan. Selesai pembawaan janturan, iringan gending Gendhing Gambir Sawit laras sléndro pathet sanga disuwuk antal sesuai abaaba dhodhogan. Peristiwa menjelang adegan perang bégal menggunakan iringan gending Playon laras sléndro pathet sanga disertai keprakan. Yang perlu dicatat pada jejer IV ialah selama adegan perang bégal menggunakan iringan gending gaya Surakarta. Adapun iringan gending yang digunakan sebagai berikut: saat Raden Arjuna berkenalan dengan barisan prajurit Jangkarbumi yang menghadangnya menggunakan Lagu Kecik-kecik laras sléndro pathet sanga. Saat Raden Arjuna melawan Ditya Kala Ènèng-ènèng Sepèg-sepèg Sekrup menggunakan iringan gending Kemuda laras pélog pathet nem disertai keprakan berubah menjadi Palaran Pangkur laras pélog pathet nem disertai keprakan. Setelah palaran tersebut iringan gending menjadi Srepeg Sanga laras pélog pathet lima gaya Surakarta disertai keprakan. Saat Ditya Kala Ėnèng-ènèng Sepèg-sepèg Sekrup mati, iringan gending Srepeg Sanga laras pélog pathet lima gaya Surakarta berubah menjadi Sampak Sanga laras sléndro pathet sanga gaya Surakarta disertai keprakan hingga disuwuk gropak sesuai aba-aba keprakan. Kemudian Raden Arjuna melawan Ditya Kala Pragalba menggunakan iringan gending Sampak Sanga laras sléndro pathet sanga gaya Surakarta disertai keprakan. Ditya Kala Pragalba mati. Iringan gending Sampak Sanga laras sléndro pathet sanga gaya Surakarta disuwuk gropak sesuai aba-aba keprakan. Raden Arjuna melawan Ditya Kala Bedhag-bedhagal menggunakan iringan gending Sampak Sanga laras sléndro pathet sanga gaya Surakarta disertai keprakan. Terjadi perang gecul antara punakawan melawan Ditya Kala Bedhag-bedhagal diiringi dengan umpak-umpakan Lagu Rondha Malam laras sléndro pathet sanga. Ditya Kala Bedhag-bedhagal mati. Ditya Kala Montrokendho maju, namun berhasil diundurkan 
oleh Raden Arjuna diiringi iringan gending Sampak Sanga laras sléndro pathet sanga gaya Surakarta disertai keprakan berubah menjadi Ayak-ayakan Sanga laras sléndro pathet sanga gaya Surakarta hingga disuwuk antal sesuai aba-aba dhodhogan. Struktur iringan gending adegan perang bégal Lakon Kalimasada versi Ki Timbul Hadiprayitno dapat dilihat pada tabel 3.

Tabel 3. Pembagian iringan gending adegan perang bégal Lakon Kalimasada versi Ki Timbul Hadiprayitno.

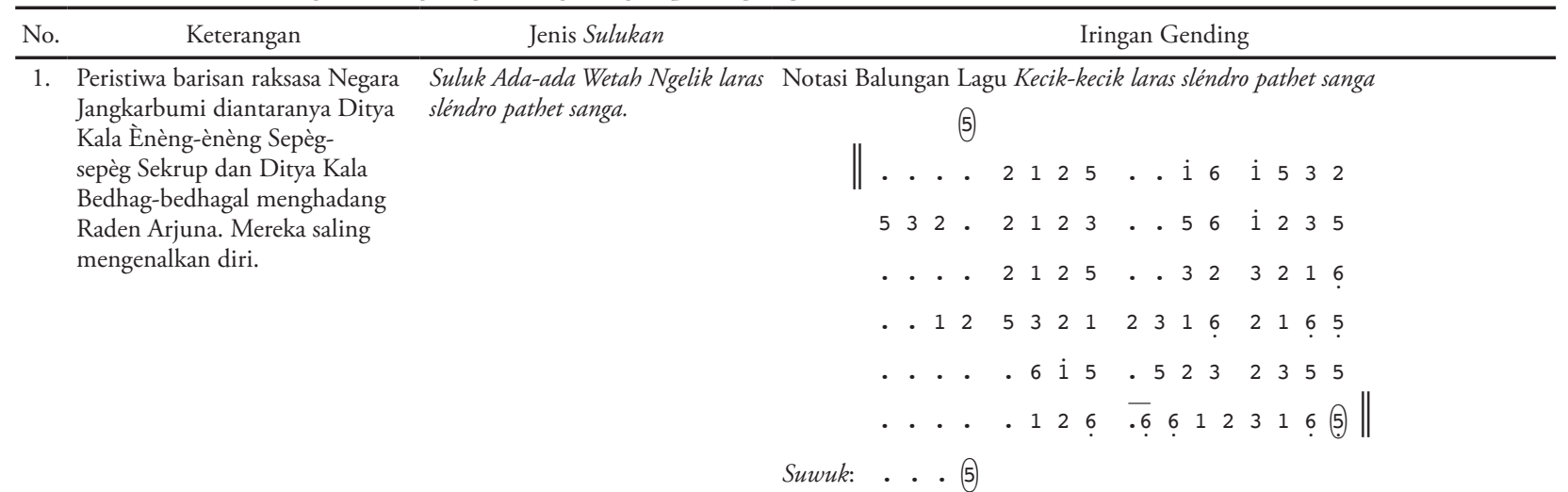

2. Terjadi perselisihan antara Raden Arjuna dengan Ditya Kala Ėnèng-ènèng Sepègsepèg Sekrup hingga terjadi peperangan.

3. Raden Arjuna melawan kedua raksasa. Ditya Kala Ènèng-ènèng Sepèg-sepèg Sekrup kewalahan, kemudian mengeluarkan senjata keris nawantaka dan kembali melawan Arjuna. Ditya Kala Ènèng-ènèng Sepèg-sepèg Sekrup kembali terdesak hingga mati. Ditya Pragalba datang menghadang Arjuna.
Suluk Ada-ada Greget Sahut Sanga Jugag laras sléndro pathet sanga gaya Surakarta.
Notasi Balungan Kemuda laras pélog pathet nem

Buka: kendhang (6)

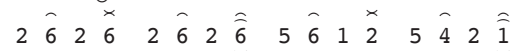

$$
\begin{aligned}
& \begin{array}{llllllllllllllll}
6 & \hat{5} & 4 & \breve{5} & 4 & \hat{2} & 4 & 5 & 4 & 2 & 4 & \widehat{5} & 3 & 3 & 5 & 6
\end{array}
\end{aligned}
$$

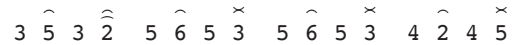

$$
\begin{aligned}
& \begin{array}{lllllllllllllllll}
4 & \hat{2} & 4 & \hat{5} & 4 & \hat{2} & 4 & \hat{5} & 3 & \hat{2} & 1 & 2 & 3 & \hat{2} & 1 & \hat{6}
\end{array} \\
& \mid \begin{array}{||llllllllllllllll}
2 & \hat{\sigma} & 2 & \bar{\sigma} & 2 & \hat{\sigma} & 2 & \hat{\bar{\sigma}} & 3 & \overline{3} & 2 & 3 & 2 & \hat{1} & 2 & \hat{\overline{1}}
\end{array} \\
& \begin{array}{llllllllllllllll}
6 & \hat{5} & 4 & \breve{5} & 4 & \hat{2} & 4 & \breve{5} & 4 & \hat{2} & 4 & \hat{5} & 3 & \hat{2} & 1 & 2
\end{array} \\
& \begin{array}{llll}
3 & \hat{2} & 1 & \hat{6}
\end{array}
\end{aligned}
$$

Palaran Pangkur laras pélog pathet nem gaya Surakarta

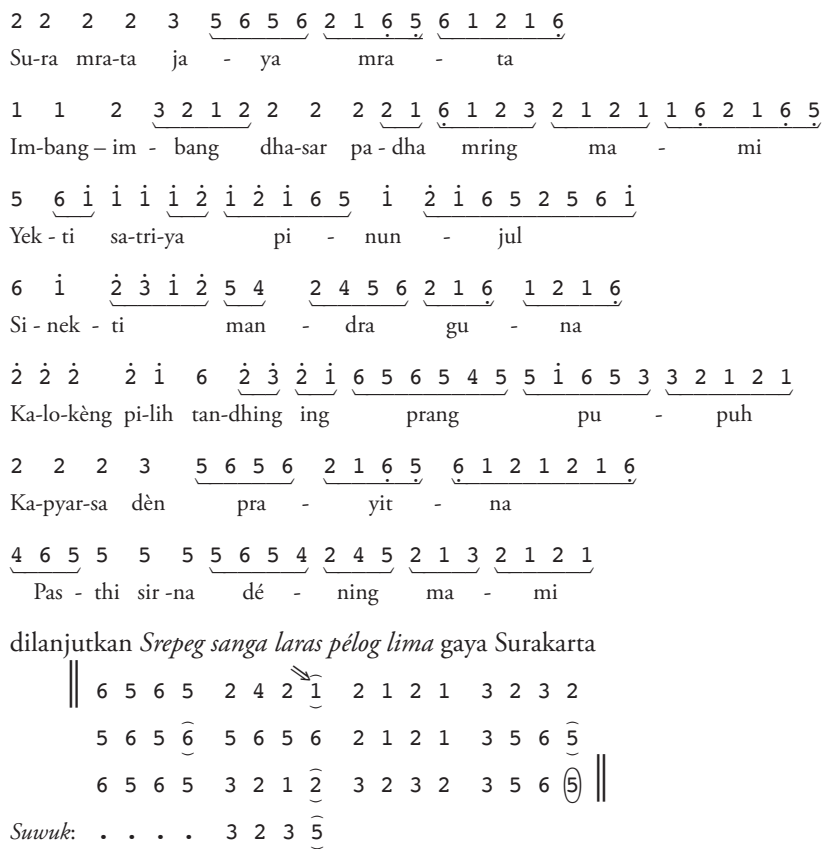

beralih menjadi Sampak Sanga laras sléndro pathet sanga gaya Surakarta (5)

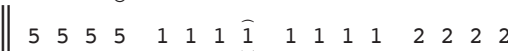

$\begin{array}{llllllllllllllll}6 & 6 & 6 & \overline{6} & 6 & 6 & 6 & 6 & 1 & 1 & 1 & 1 & 5 & 5 & 5 & \overline{5}\end{array}$

$\begin{array}{llllllllllllllll}5 & 5 & 5 & 5 & 2 & 2 & 2 & \overline{2} & 2 & 2 & 2 & 2 & 5 & 5 & 5 & (5)\end{array}$

Suwnk: .. 5555 
4. Ditya Pragalba menantang Arjuna. Terjadi perselisihan hingga berujung peperangan. Ditya Pragalba kalah.

Punakawan membuang jasad Ditya Pragalba.

5. Ditya Kala Bedhag-bedhagal datang menantang Arjuna. Terjadi perselisihan hingga berujung peperangan. Perang gecul antara Ditya Kala Bedhagbedhagal melawan Raden Arjuna. Ditya Kala Bedhagbedhagal kalah.

6. Ditya Kala Montrokendho datang menantang Arjuna. Punakawan mengajak bercanda Ditya Kala Montrokendho. Terjadi perselisihan hingga berujung peperangan. Perang gecul antara Ditya Kala Montrokendho melawan punakawan. Ditya Kala Montrokendho kéntas melarikan diri dari medan laga. Diakhiri pembawaan carita yang menceritakan para prajurit raksasa yang masih tersisa berlarian memasuki hutan.
Suluk Ada-ada Palaran laras sléndro pathet sanga gaya Surakarta dan Suluk Adaada Greget Sahut Sanga Jugag laras sléndro pathet sanga gaya Surakarta.

Suluk Ada-ada Greget Sahut Sanga Jugag laras sléndro pathet sanga gaya Surakarta.

Suluk Ada-ada Greget Sahut Sanga Jugag laras sléndro pathet sanga gaya Surakarta.

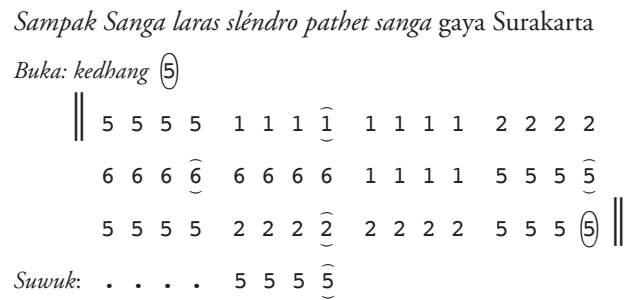

Notasi Balungan Umpak-umpakan Lagu Rondha Malam laras sléndro pathet sanga

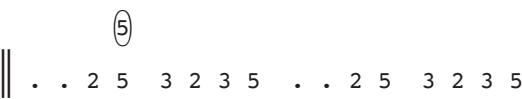

$$
\begin{aligned}
& \text {. } 6 \text { i. } 65 \text { i } 6 \text {. . i } 65 \text { i } 65
\end{aligned}
$$

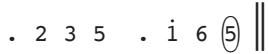

Sampak Sanga laras sléndro pathet sanga gaya Surakarta Buka: kedhang 5

$$
\begin{array}{||llllllllllllllll}
5 & 5 & 5 & 5 & 1 & 1 & 1 & 1 & 1 & 1 & 1 & 1 & 2 & 2 & 2 & 2 \\
6 & 6 & 6 & \overline{6} & 6 & 6 & 6 & 6 & 1 & 1 & 1 & 1 & 5 & 5 & 5 & 5 \\
5 & 5 & 5 & 5 & 2 & 2 & 2 & \widehat{2} & 2 & 2 & 2 & 2 & 5 & 5 & 5 & 5
\end{array} \|
$$

ndhawah menjadi Ayak-ayakan Sanga laras sléndro pathet sanga gaya Surakarta

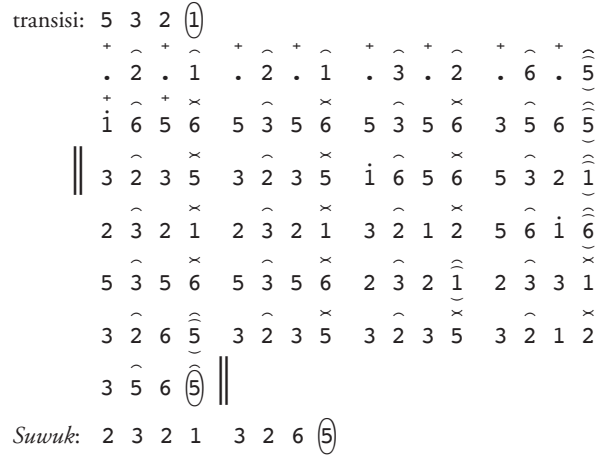


golek gambyongan. Setelah tarian wayang golek tersebut tanceb kayon. Iringan gending Ladrang Samiran laras sléndro pathet manyura pindah menjadi Ayak-ayak Pamungkas laras sléndro pathet manyura gaya Surakarta hingga disuwuk antal sesuai aba-aba dhodhogan.

Secara keseluruhan penggunaan iringan gending pada wilayah pathet manyura Lakon Kalimasada sesuai dengan iringan gending pakeliran gaya Yogyakarta pada umumnya. Hanya pada iringan gending penutup pementasan menggunakan iringan gending Ayak-ayak Pamungkas laras sléndro pathet manyura gaya Surakarta. Hal tersebut tidak menjadi masalah dan tidak mempengaruhi jalannya peristiwa pada wilayah pathet manyura tersebut.

Sulukan merupakan salah satu bagian dari unsur iringan. Pada dasarnya sulukan dipergunakan untuk mendeskripsikan setiap peristiwa atau adegan yang sedang ditampilkan (Kasidi, 2009: 28). Dalam Lakon Kalimasada terdapat beberapa jenis sulukan gaya pedalangan Yogyakarta yang sering muncul. Di samping sulukan gaya Yogyakarta, Ki Timbul Hadiprayitno juga sering melantunkan sulukan gaya Surakarta. Jenis sulukan gaya pedalangan Yogyakarta tersebut antara lain: Suluk Dhendha laras sléndro pathet nem yang dimulai dengan larasan lima, Suluk Ada-ada Wetah Ngelik laras sléndro pathet nem dimulai dengan larasan jangga alit (oktaf tinggi), Suluk Lagon Wetah laras sléndro pathet sanga dimulai dengan larasan jangga, dan Suluk Ada-ada Wetah Ngelik laras sléndro pathet sanga dimulai dengan larasan jangga alit (oktaf tinggi). Sesuai pengamatan di lapangan, tidak hanya Ki Timbul Hadiprayitno namun banyak seniman dalang gaya Yogyakarta juga sering melantunkan ketiga jenis sulukan tersebut dalam pementasannya. Ki Timbul Hadiprayitno juga melantunkan beberapa sulukan gaya Surakarta pada bagian adegan perang bégal Lakon Kalimasada.

Pada wilayah pathet nem Lakon Kalimasada, $\mathrm{Ki}$ Timbul Hadiprayitno melantunkan Suluk Dhendha laras sléndro pathet nem disertai dhodhogan dalam jejer I, yaitu saat Pandhita Durna hendak menggagalkan keberhasilan Pandhawa dalam mencari ketiga pusaka kahyangan. Ia akan dibantu oleh Bathara Naga Cundhila dan putranya yang bernama Prabu Bagindharaja dari Negara Jangkarbumi. Berikut Suluk Dhendha laras sléndro pathet nem versi Ki Timbul Hadiprayitno.

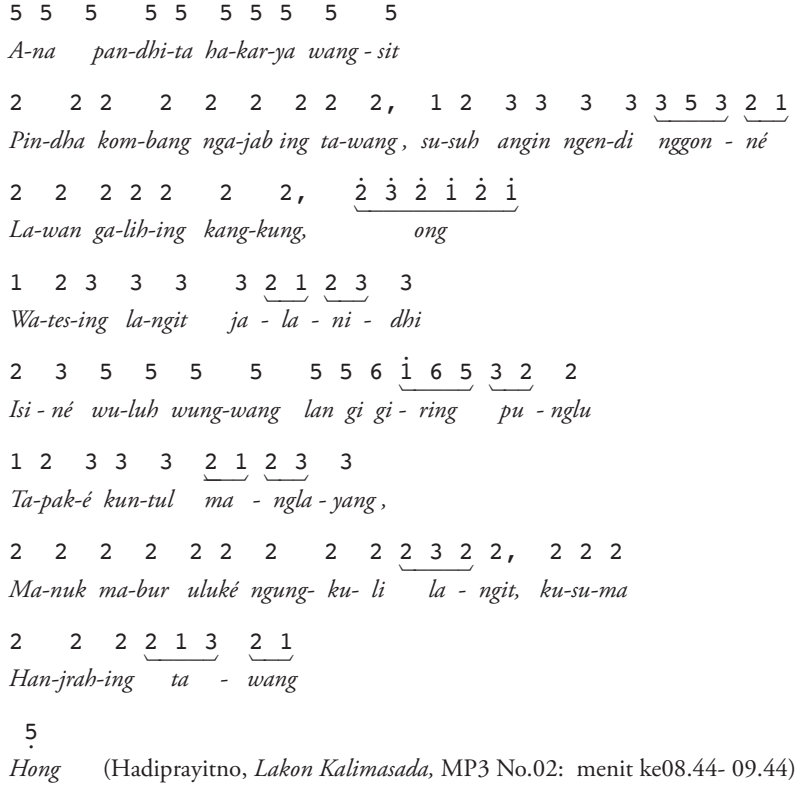

Adegan paséban njawi Lakon Kalimasada terjadi di Alun-alun Negara Ngastina. Raden Durmagati, Raden Dursasana, Raden Citraksa, Raden Citraksi, dan Raden Jayadrata menghadap Patih Sengkuni di Alun-alun Negara Ngastina. Setelah iringan gending Playon Lasem laras sléndro pathet nem disuwuk tanggung, dalang melantunkan Suluk Ada-ada Wetah Ngelik laras sléndro pathet nemdisertai dhodhogan. Berikut uraian jenis Suluk Ada-ada Wetah Ngelik laras sléndro pathet nem versi Ki Timbul Hadiprayitno.

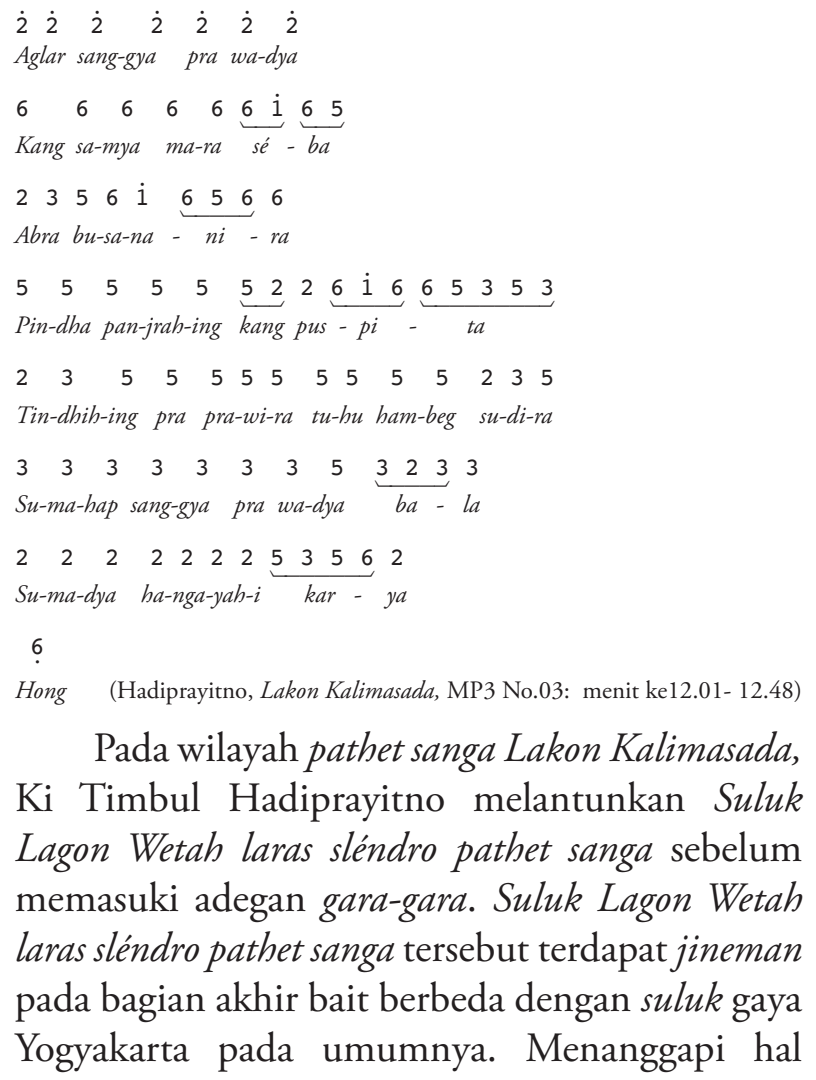

Hong (Hadiprayitno, Lakon Kalimasada, MP3 No.03: menit ke12.01- 12.48)

Pada wilayah pathet sanga Lakon Kalimasada, Ki Timbul Hadiprayitno melantunkan Suluk Lagon Wetah laras sléndro pathet sanga sebelum memasuki adegan gara-gara. Suluk Lagon Wetah laras sléndro pathet sanga tersebut terdapat jineman pada bagian akhir bait berbeda dengan suluk gaya Yogyakarta pada umumnya. Menanggapi hal 
tersebut, Ki Margiyana (wawancara, 02 April 2016) mengungkapkan:

"Kyainé kuwi pancèn kawit biyèn ngono Mas, nék Suluk Lagon Sanga arepé garagara, kerep-kerepé ana jinemané. Suluké kuwi pancèn béda karo cara Yoja, nék sing ana jinemané kuwi semuné sulukan cara Kedhu utawa cara Banyumas."

('Kyainya [sebutan Ki Timbul Hadiprayitno] itu memang sejak dulu seperti itu Mas, kalau melantunkan Suluk Lagon Sanga menjelang adegan gara-gara seringseringnya terdapat jineman-nya [pada bait bagian akhir]. Suluknya memang berbeda dengan suluk gaya Yogyakarta, kalau yang ada jineman-nya memang menyerupai sulukan gaya Kedu atau gaya Banyumas.')

Ki Timbul Hadiprayitno memasukkan variasi jenis sulukan dari daerah lain ke dalam pakelirannya saat menjelang adegan gara-gara. Suluk Lagon Wetah laras sléndro pathet sanga menjelang adegan garagara tersebut justru menjadi ciri khasnya. Berikut uraian dan céngkok Suluk Lagon Wetah laras sléndro pathet sanga versi Ki Timbul Hadiprayitno.

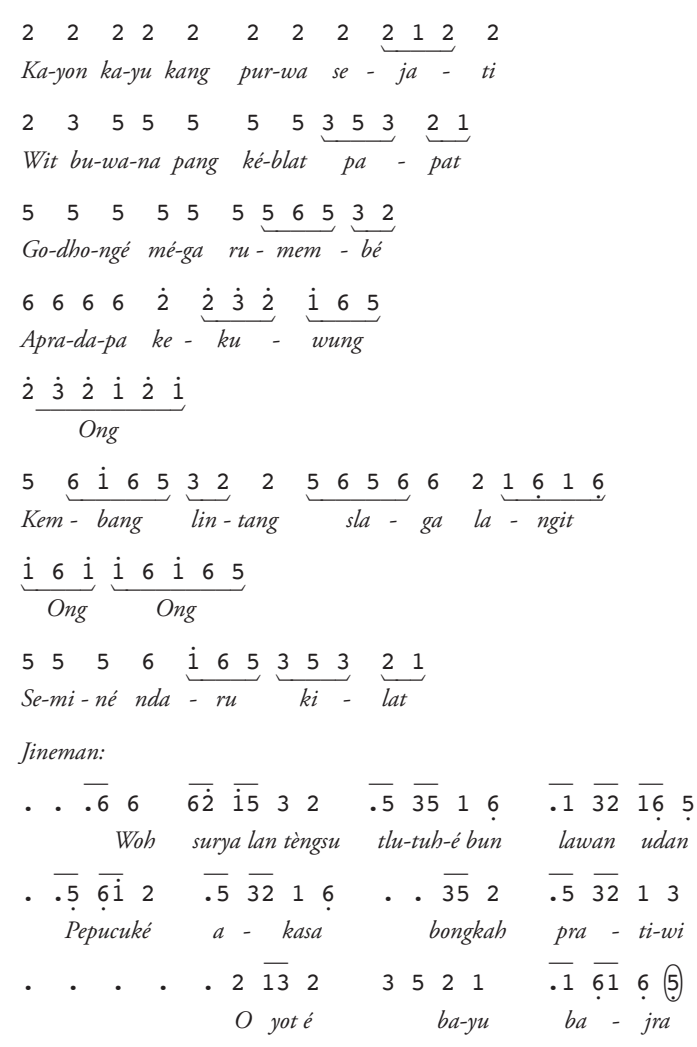

(Hadiprayitno, Lakon Kalimasada, MP3 No.05: menit ke11.35 - 13.41)

Pada sela-sela kandha carita menjelang adegan gara-gara Lakon Kalimasada terdapat Suluk Ada- ada Wetah Ngelik laras sléndro pathet sanga. Jenis sulukan tersebut versi Ki Timbul Hadiprayitno. Berikut Suluk Ada-ada Wetah Ngelik laras sléndro pathet sanga versi Ki Timbul Hadiprayitno.

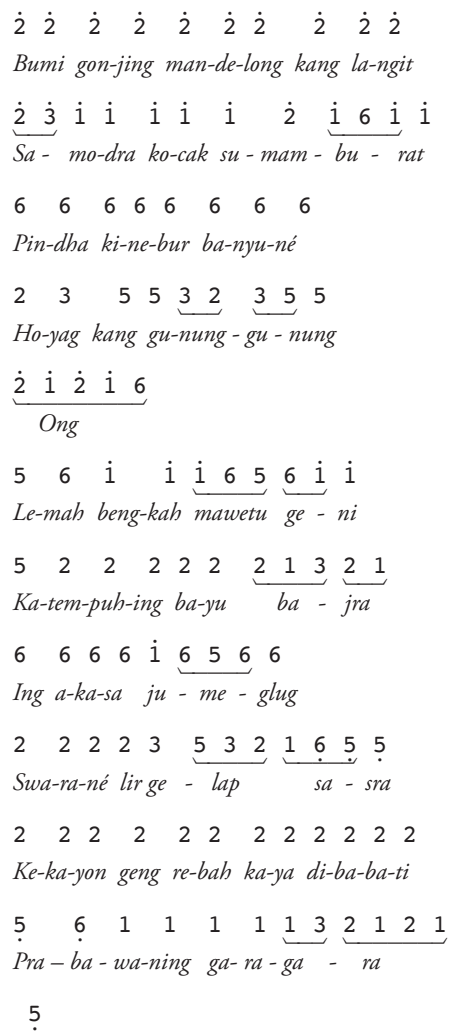

Pada adegan perang bégal Lakon Kalimasada terdapat penggantian sulukan yang digunakan Ki Timbul Hadiprayitno. Beliau menggunakan sulukan gaya Surakarta pada rangkaian peristiwa yang terjadi selama adegan perang bégal. Hal demikian terkait dengan iringan gending adegan perang bégal yang menggunakan iringan gending gaya Surakarta. Berikut sulukan gaya Surakarta yang digunakan dalam rangkaian peristiwa adegan perang bégal Lakon Kalimasada: Saat peristiwa perselisihan pembicaraan antara Ditya Kala Ènèngènèng Sepèg-sepèg Sekrup dengan Raden Arjuna hingga terjadi peperangan menggunakan Suluk Ada-ada Greget Sahut Sanga Jugag laras sléndro pathet sanga gaya Surakarta disertai dhodhogan; Peristiwa Ditya Kala Ènèng-ènèng Sepèg-sepèg Sekrup mati. Ditya Pragalba maju menghadang Raden Arjuna menggunakan Suluk Ada-ada Palaran laras sléndro pathet sanga gaya Surakarta disertai dhodhogan; Peristiwa Ditya Kala Pragalba mati. Ditya Kala Bedhag-bedhagal maju menghadang Raden Arjuna dan punakawan menggunakan Suluk Ada-ada Greget Sahut Jugag laras sléndro pathet 
sanga gaya Surakarta disertai dhodhogan; Peristiwa Ditya Kala Bedhag-bedhagal mati. Ditya Montro Kendho menghadang Arjuna dan punakawan menggunakan Suluk Ada-ada Greget Sahut Sanga
Jugag laras sléndro pathet sanga gaya Surakarta disertai dhodhogan. Sulukan yang terdapat dalam adegan perang bégal Lakon Kalimasada versi Ki Timbul Hadiprayitno dapat dilihat pada tabel 4.

Tabel 4. Pembagian sulukan adegan perang bégal Lakon Kalimasada versi Ki Timbul Hadiprayitno.

\begin{tabular}{|c|c|c|c|}
\hline No. & Keterangan & Jenis Sulukan & Iringan Gending \\
\hline 1. & $\begin{array}{l}\text { Peristiwa barisan raksasa Negara } \\
\text { Jangkarbumi diantaranya Ditya } \\
\text { Kala Ėnèng-ènèng Sepèg- } \\
\text { sepèg Sekrup dan Ditya Kala } \\
\text { Bedhag-bedhagal menghadang } \\
\text { Raden Arjuna. Mereka saling } \\
\text { mengenalkan diri. }\end{array}$ & $\begin{array}{l}\text { Lagu Kecik-kecik laras sléndro } \\
\text { pathet sanga. }\end{array}$ & 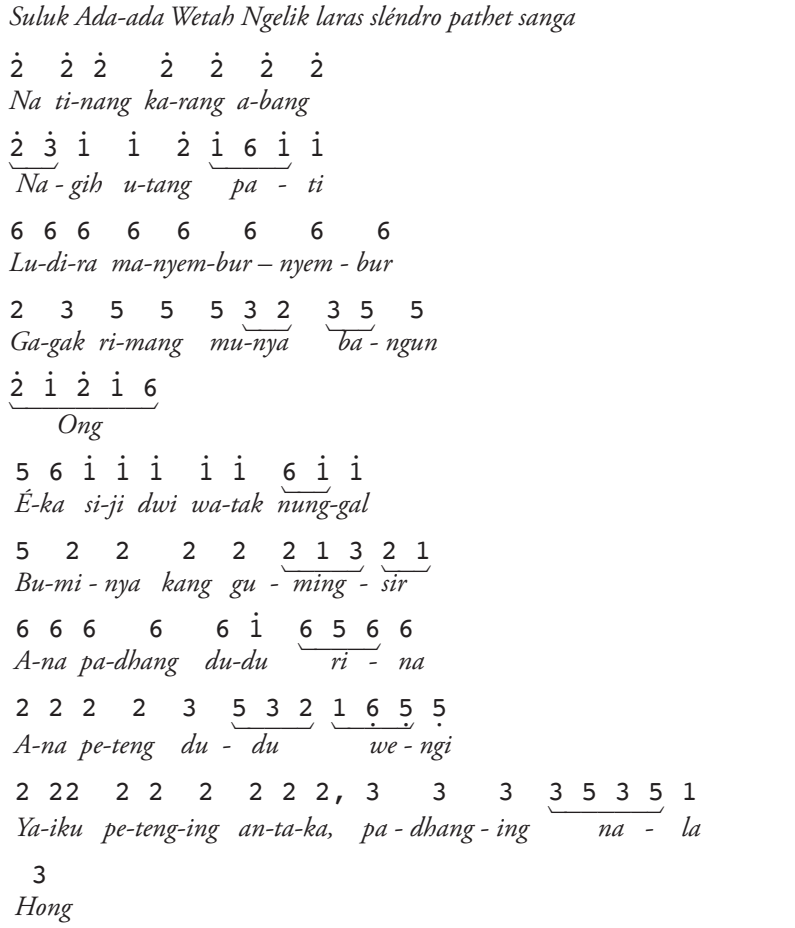 \\
\hline 2. & $\begin{array}{l}\text { Terjadi perselisihan antara } \\
\text { Raden Arjuna dengan Ditya } \\
\text { Kala Ènèng-ènèng Sepèg- } \\
\text { sepèg Sekrup hingga terjadi } \\
\text { peperangan. }\end{array}$ & Kemuda laras pélog pathet nem. & 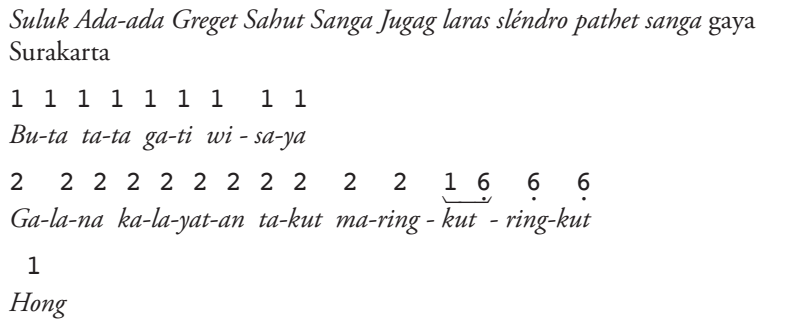 \\
\hline 3. & $\begin{array}{l}\text { Raden Arjuna melawan kedua } \\
\text { raksasa. Ditya Kala Ėnèng-ènèng } \\
\text { Sepèg-sepèg Sekrup kewalahan, } \\
\text { kemudian mengeluarkan senjata } \\
\text { keris nawantaka dan kembali } \\
\text { melawan Arjuna. Ditya Kala } \\
\text { Ènèng-ènèng Sepèg-sepèg } \\
\text { Sekrup kembali terdesak hingga } \\
\text { mati. Ditya Pragalba datang } \\
\text { menghadang Arjuna. }\end{array}$ & $\begin{array}{l}\text { Palaran Pangkur laras pélog pathet } \\
\text { nem gaya Surakarta, dilanjutkan } \\
\text { Srepeg Sanga laras pélog lima } \\
\text { gaya Surakarta beralih menjadi } \\
\text { Sampak Sanga laras sléndro pathet } \\
\text { sanga gaya Surakarta. }\end{array}$ & - \\
\hline 4. & $\begin{array}{l}\text { Ditya Pragalba menantang } \\
\text { Arjuna. Terjadi perselisihan } \\
\text { hingga berujung peperangan. } \\
\text { Ditya Pragalba kalah. } \\
\text { Punakawan membuang jasad } \\
\text { Ditya Pragalba. }\end{array}$ & $\begin{array}{l}\text { Sampak Sanga laras sléndro pathet } \\
\text { sanga gaya Surakarta. }\end{array}$ & 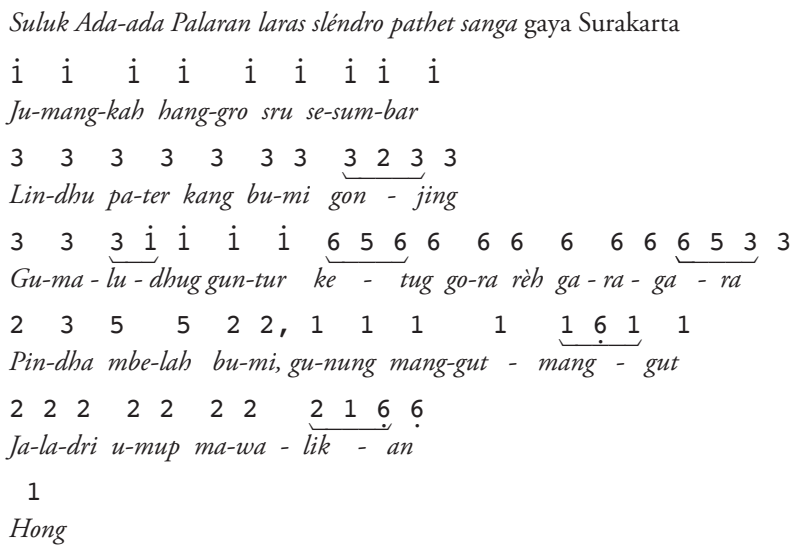 \\
\hline
\end{tabular}


5. Ditya Kala Bedhag-bedhagal datang menantang Arjuna. Terjadi perselisihan hingga berujung peperangan. Perang gecul antara Ditya Kala Bedhagbedhagal melawan Raden Arjuna. Ditya Kala Bedhagbedhagal kalah.

6. Ditya Kala Montrokendho datang menantang Arjuna. Punakawan mengajak bercanda Ditya Kala Montrokendho. Terjadi perselisihan hingga berujung peperangan. Perang gecul antara Ditya Kala Montrokendho melawan punakawan. Ditya Kala Montrokendho kéntas melarikan diri dari medan laga. Diakhiri pembawaan carita yang menceritakan para prajurit raksasa yang masih tersisa berlarian memasuki hutan. dan Suluk Ada-ada Greget Sabut Sanga Jugag laras sléndro pathet sanga gaya Surakarta

$\begin{array}{llllllllllllll}1 & 1 & 1 & 1 & 1 & 1 & 1 & 1 & 1 & 1 & 1 & 1 & 1 & 1\end{array}$

Bu-mi gon-jang - gan-jing la-ngit ke-lap-ke-lap ka-ton

$\begin{array}{lllllllllllll}2 & 2 & 2 & 2 & 2 & 2 & 2 & 2 & 2 & 2 & 1 & 6 & 6\end{array}$

Lir kin-cang-ing a-lis ri-sang ma-wèh gan- drung

1

Hong

Umpak-umpakan Lagu Rondha Malam laras sléndro pathet sanga.

Suluk Ada-ada Greget Sahut Sanga Jugag laras sléndro pathet sanga gaya

Surakarta

1

Ong

$\begin{array}{lllllllllllllllll}2 & 2 & 2 & 2 & 2 & 2 & 2 & 2 & 2 & 2 & 2 & 2 & 2 & 2 & 1 & 6 & 6\end{array}$

Bu-ta ta-ta ga-ti wi-sa-ya ga-la-na ka-la-yat-an 1

Hong

Sampak Sanga laras sléndro pathet Suluk Ada-ada Greget Sahut Sanga Jugag laras sléndro pathet sanga gaya sanga gaya Surakarta ndhawah Surakarta menjadi Ayak-ayakan Sanga 1 laras sléndro pathet sanga gaya Surakarta.

Ong

$\begin{array}{lllllllllllll}2 & 2 & 2 & 2 & 2 & 2 & 2 & 2 & 2 & 2 & 1 & 6 & 6\end{array}$

Bu-ta ta-ta ga-ti wi-sa-ya ga- la -

1

Hong

Pada wilayah pathet manyura Lakon Kalimasada, Ki Timbul Hadiprayitno melantunkan Suluk Lagon Wetah laras sléndro pathet manyura untuk mengawali jejer $\mathrm{V}$ yang terjadi di Kahyangan Jonggringsaloka. Untuk penekanan peristiwaperistiwa yang terjadi digunakan Suluk Ada-ada Wetah atau Jugag laras sléndro pathet manyura atau laras pélog pathet barang. Saat dalang sudah melantunkan Suluk Lagon Galong Wetah laras sléndro pathet manyura, peristiwa-peristiwa yang terjadi setelah itu diiringi Suluk Ada-ada Galong laras sléndro pathet manyura. Sulukan yang digunakan Ki Timbul Hadi Prayitno selama wilayah pathet manyura sesuai kaidah pedalangan gaya Yogyakarta pada umumnya.

Pembahasan ketiga dalam unsur iringan terkait dengan keprakan pada Lakon Kalimasada. Peran keprakan dan dhodhogan memiliki hubungan yang erat dalam pakeliran. Peran keprakan dapat dikatakan sebagai aliran darah sedangkan peran dhodhogan sebagai detak jantung. Keprakan pada dasarnya dipergunakan sebagai daya tarik dan daya hidup setiap lakuan yang ada dalam pementasan wayang kulit purwa (Kasidi, 2009: 29). Secara umum bentuk keprakan Ki Timbul Hadiprayitno dalam Lakon Kalimasada sesuai kaidah keprakan pedalangan gaya Yogyakarta.

Teknik keprakan gaya Yogyakarta bermacammacam, diantaranya: ngeceg, neteg, nisir, nduduk, dan nyigar ada (Mudjanattistomo dkk., 1977: 14-15). Keprakan Ki Timbul Hadiprayitno dalam Lakon Kalimasada mencakup semua teknik sesuai kebutuhan untuk mengiringi dan memberi penekanan gerak wayang yang sedang ditampilkan di kelir. Selain itu keprakan juga berfungsi mengiringi suluk ada-ada dan pocapan saat suasana tegang atau situasi tertentu, serta sebagai aba-aba isyarat untuk menghentikan iringan gending yang sedang ditabuh. Jika diamati ciri khas teknik keprakan Ki Timbul adalah keprakan nyigar ada. Para dalang di Yogyakarta selain beliau, apabila memainkan keprak gaya Yogyakarta saat iringan gending playon umumnya menggunakan teknik keprakan nisir. Kekonsistenan Ki Timbul Hadiprayitno terlihat saat penekanan gerak wayang di kelir semisal wayang kéntas dari kelir, wayang menghantam, dan penekanan gerak lainnya, beliau tetap mengkombinasikan teknik keprakan nduduk 
dengan keprakan neteg. Menanggapi hal tersebut, Ki Cermagupita (wawancara, 23 Februari 2017) mengungkapkan:

"Keprakan cara Yoja kuwi titènané nduduk 'grejag-jag-jag-jag-jagjagjag'. Nék kanggo solah wayang ngantem, mbanting, tiba, tambahi neteg pas kèri dhéwé dadiné 'grejagjag-jag-jag-jagjagjag-jag’. Solah liyané kuwi aja 'jag-jèg-jag-jèg', dirungoké, dirasaké ora kepénak, malah dadi ngregeti solahé wayang sing ning kelir".

(Keprakan gaya Yogyakarta itu ciri-cirinya adalah teknik keprakan nduduk 'grejagjag-jag-jag-jagjagjag'. Kalau untuk gerak wayang menghantam, membanting, dan jatuh ditambahi teknik keprakan neteg pada bagian akhir, jadinya 'grejag-jag-jagjag-jagjagjag- jag'. Gerak wayang selain itu keprakannya jangan 'jag-jèg-jag-jèg', didengar dan dirasakan tidak enak, justru jadi mengotori gerak wayang di kelir.')

Pembahasan keempat dalam unsur iringan adalah dhodhogan pada Lakon Kalimasada. Sudah disampaikan di atas bahwa peran dhodhogan dan keprakan memiliki hubungan erat dalam pakeliran. Jika keprakan dibahas maka dhodhogan juga harus dibahas. Mereka adalah jantung dan aliran darah dalam pakeliran. Teknik dhodhogan gaya Yogyakarta bermacam-macam, diantaranya: neteg, mlatuk, geter, banyu tumètès, dan nyigar ada (Mudjanattistomo dkk., 1977: 14-15). Dhodhogan Ki Timbul Hadiprayitno dalam Lakon Kalimasada mencakup semua teknik yang telah disebutkan. Peran dhodhogan biasanya sebagai abaaba isyarat untuk mengawali pementasan, untuk mengiringi, dan sebagai jeda saat pocapan, kandha, carita, sebagai isyarat aba-aba untuk meminta iringan gending yang hendak ditabuh, dan untuk menghentikan iringan gending yang sedang ditabuh dengan istilah suwuk antal. Teknik dhodhogan Ki Timbul Hadiprayitno saat pocapan, kandha, dan carita dalam suasana tenang menggunakan teknik dhodhogan mlatuk yang dikombinasikan dengan teknik keprakan neteg, biasa disebut dengan teknik dhodhogan mlatuk neteg atau dhodhogan banyu tumètès. Dhodhogan sebagai aba-aba untuk meminta iringan gending pada para niyaga, menyesuaikan kebutuhan adegan dan kebutuhan suasana yang sedang dikelirkan. Teknik dhodhogan yang dipakai untuk meminta iringan gending pada adegan jejer, yaitu setelah dalang mengucapkan sasmita iringan gending yang dibutuhkan kemudian mengakhirinya dengan dhodhogan mlatuk neteg. Teknik dhodhogan untuk meminta iringan gending playon, yaitu setelah dalang selesai dialog atau membawakan carita kemudian mengakhirinya dengan dhodhogan mlatuk neteg dilanjutkan dhodhogan geter. Teknik dhodhogan untuk meminta iringan sampak, yaitu setelah dalang selesai pocapan atau carita kemudian mengakhirinya dengan dhodhogan nyigar ada dilanjutkan dhodhogan geter.Saat membawakan pocapan atau carita dalam suasana tegang menggunakan teknik dhodhogan geter untuk dapat membangun suasana dan menaikkan emosi pada peristiwa yang sedang berlangsung.

Secara umum terkait teknik, peran, dan fungsi keprakan serta dhodhogan yang dimainkan oleh $\mathrm{Ki}$ Timbul Hadiprayitno dalam Lakon Kalimasada tidak berbeda dengan keprakan dan dhodhogan gaya Yogyakarta. Ciri khas keprakan Ki Timbul justru terlihat saat mengiringi setiap iringan gending playon. Pada umumnya keprakan pedalangan gaya Yogyakarta saat mengiringi iringan gending playon menggunakan teknik keprakan nisir, sedangkan Ki Timbul Hadiprayitno menggunakan teknik keprakan nyigar ada. Kekonsistenan beliau terhadap keprak gaya Yogyakarta juga tampak pada saat adegan perang bégal Lakon Kalimasada yang tetap menggunakan keprak gaya Yogyakarta, walaupun iringan gending dan sulukan saat adegan perang bégal tersebut menggunakan gaya Surakarta.

\section{Fleksibilitas dan Pengurangan dalam Unsur Naratif Lakon Kalimasada versi Ki Timbul Hadiprayitno}

Unsur naratif dalam caking pakeliran gaya Yogyakarta meliputi: janturan, kandha, carita, dan pocapan (Mudjanattistomo dkk., 1977: 14). Pertama-tama akan dibicarakan mengenai fleksibilitas unsur naratif dari Lakon Kalimasada yang terjadi pada janturan. Janturan yang akan dibahas adalah janturan pada jejer I, dikarenakan pembagian isi dalam janturan tersebut sangat kompleks dibandingkan dengan janturan pada adegan jejer lainnya. Isi dalam janturan jejer I mencakup deskripsi mengenai latar tempat, latar 
waktu, tokoh wayang yang terlibat, kewibawaan tokoh, busana tokoh, dan suasana yang sedang terjadi dalam adegan tersebut. Isi janturan pada jejer II, jejer IV, dan jejer V sudah menyesuaikan dan mengikuti pergerakan cerita dalam lakon yang dipentaskan.

Janturan jejer I menceritakan pasowanan agung di Negara Ngastina. Pada dasarnya isi janturan jejer I Negara Ngastina Lakon Kalimasada versi Ki Timbul Hadiprayitno sama dengan isi janturan gaya Yogyakarta lainnya, jadi tidak ada keistimewaan dalam janturan tersebut. Isi janturan tersebut meliputi: doa pembuka (purwaka janturan), deskripsi sebuah negara beserta kerajaannya, deskripsi sosok raja pemimpin yang besar, suasana yang terjadi di pasowanan agung, dan tokoh-tokoh yang hadir di pasowanan agung.

Mudjanattistomo dkk. (1977: 14) menyatakan bahwa kandha adalah wacana yang diucapkan dalang berupa deskripsi sebuah peristiwa yang telah terjadi. Pembawaan kandha dalam pakeliran tidak disertai tokoh wayang yang dikelirkan. Dalam membawakan kandha, wayang gunungan ditancapkan di bagian tengah kelir dengan posisi miring ke kanan, ke kiri, atau tegak sesuai wilayah pathet yang sedang berlangsung serta diselingi dhodhogan sesuai kebutuhan. Pembawaan kandha biasanya tanpa disertai iringan gending. Pembawaan kandha pada Lakon Kalimasada terjadi setelah prosesi kondur ngedhaton, menjelang jejer II, dan menjelang adegan gara-gara. Biasanya pembawaan kandha pada ketiga bagian tersebut disambung dengan pembawaan carita. Namun pembahasan ini difokuskan pada kandha.

Mengingat adanya penggantian adegan kondur ngedhaton dalam Lakon Kalimasada diganti menjadi peristiwa limbukan, menyebabkan terjadinya penyingkatan dalam pembawaan kandha. Ki Timbul terlihat fleksibel dalam membawakan kandha setelah peristiwa limbukan. Tampak hanya terdapat satu kalimat yang menceritakan bahwa Prabu Duryudana telah selesai melakukan prosesi kondur ngedhaton dan bertemu dengan Dewi Banowati. Selesai pembawaan kandha dilanjutkan dengan pembawaan carita akan berlangsungnya adegan paséban njawi.

Kiranya bentuk kandha kondur ngedhaton yang singkat tersebut disebabkan karena adegan tersebut digedhong. Dalam lakon lain misalnya Lakon Imandaya Nutuh yang tidak terdapat peristiwa limbukan, Ki Timbul membawakan kandha usai adegan kondur ngedhaton secara lengkap. Kandha setelah peristiwa limbukan Lakon Kalimasada versi Ki Timbul Hadiprayitno dan kandha kondur ngedhaton Lakon Imandaya Nutuh versi Ki Timbul Hadiprayitno dapat dilihat pada tabel 5.

Tabel 5. Kandha kondur ngedhaton versi Ki Timbul Hadiprayitno dalam Lakon Kalimasada dan Lakon Imandaya Nutuh.

\section{Lakon Kalimasada}

"Sinigeg ingkang wonten salebeting dhatulaya, Prabu Duryudana nutug dènnya suka parisuka linadosan déning ingkang garwa Dèwi Banowati...

(Hadiprayitno, Lakon Kalimasada, MP3 No. 03: menit ke 08.27-08.37)

Terjemahan:

'Sekian cerita saat berada di dalam dhatulaya, Prabu Duryudana didampingi Dewi Banowati usai (suka parisuka) dhahar kembulbojana sekaligus menyaksikan hiburan tari-tarian para abdi keraton...'

\section{Lakon Imandaya Nutuh}

"Katara pasemoné Sang Nata kondur ngedhaton yayah mangku duka, kinarya pratandha wonten Kamandhungan datan kepareng kèndel, Brejanala datan kersa kèndel, Sri Panganti datan kepareng pinarak, kersa kèndel wonten ngajenging gapura Negari Dwarawati winastan kori Danapratapa. Mila ta winastan Danapratapa, danané lamun kinarya lumaksana sanggyaning para agung putra putri mbabar ganda arum, tapané lamun ana udan kudanan, panas kepanasen, keparenga Sang Nata arsa lipur driya kang nedheng sungkawa mriksa rerengganing gapura, gengnya saprabata suta, inggil ngungkuli pucang myang tirisan, musthikaning gapura sinung maniking warih sak woh jenggi rebut sorot kaliyan Hyang Pratanggapati, kang kinarya jarambah akik bang jubinan, adeg wesi balitung, sirap prunggu sari, tetebèng tembaga, ngenguwung kaya kluwung ngunjuk warih, kori kang kinarya wreksa cendhana murni, dèn ukir-ukir pinarada jenar katon èdi, madyaning kori kaparingan gedhah ginuwang rasané, nglebeting gedhah kaparingan gambar jalma jalu tuwin wanita, awit seka bisané ingkang nggambar sirna sipating gambar yayah manungsa sawantah, ora mokal yèn kori pinuju minep gambar kaya mantèn pinanggihken, lamun pinuju menga kadya bédhang posah-pasihan, kanan kéring kori pinaringan reca gupala, sayekti séla dèn enthakara gandarwa, rengganing reca kang kinarya rikma pamor, nétra kumala, untu salaka menur, ilat mas jingga, asta kanan cinepengan bindi, kéring cinepengan tamèng, karna jinara trus, grana nglebet dén wismani bramara-bramari, tegesé kombang lanang kombang wadon, jeglèging kori menga minep kagèt kombang miber, reca kaya bisa gereng-gereng nubruk gabrus. Wauta, kepareng Sang Nata nglajengaken tindak jumangkah kori Danapratapa, kacarita ingkang wonten salebeting dhatulaya garwa dalem prameswari, telu-teluning atunggal Dèwi Jembawati, Rukmini, Setyaboma. Dupi wonten pratandha Sang Nata kondur ngedhaton garwa tiga sesarengan mapag kondurnya keng raka saking panangkilan, pinanggya keng raka garwa tetiga sareng mendhak, ngejumken asta hanguswa pada, gya kadhèrèkaken 
manjing salebeting Bangsal Manis linadosan pésta raja, bawané Sang Nata pindha ngembeng sungkawa datan kepareng minangkani panuwunira ingkang garwa, amung lajeng imbal pangandikan. Dupi dènnya wus paring pangandika gya manjing Panti Busana nyarèkaken kapraboning naréndra ngrasuk busana kang sarwa séta, ngèsthi dupa ratus, genging padupan samestaka liman, lon-lonan minggah Sanggar Pamujan, Sang Nata wus kepareng muja semadi meminta sihing Hyang Widdi".

(Hadiprayitno, Lakon Kalimasada, MP3 No.02: menit ke 31.24 - 34.50)

Terjemahan:

'Terlihat raut wajah sang raja seperti sedang menyimpan masalah. Terbukti di Kamandhungan tidak berhenti, di Brejanala tidak berhenti, di Bangsal Sri Panganti juga tidak berhenti, bersedia berhenti di depan gapura Negara Dwarawati, disebut (pintu) koriDanapratapa. Dinamakan Danapratapa karena, dana yang berarti sebagai jalur utama yang dilewati segenap bangsawan, baik yang putra ataupun putri, saat mereka lewat menebarkan aroma wangi di sekitar gapura; tapa artinya jika hujan gapura dapat kehujanan, jika terik panas gapura tetap terkena panas. Sang raja melepas kepenatan dengan melihat hiasan yang berada di gapura dan sekitarnya, besarnya gapura bagaikan sebesar anak gunung, tingginya melebihi pohon pucang, di bagian atas gapura terdapat batu permata yang besarnya melebihi buah kelapa, hingga memantulkan sinar seperti matahari, lantai terbuat dari marmer yang disertai dengan batu mutiara, tiang gapura terbuat dari besi balitung, sisi atap gapura terbuat dari perunggu pilihan, kanan kiri gapura terdapat ukir-ukiran tembaga bagaikan pelangi yang muncul dari permukaan air,pintu gapura terbuat dari kayu cendana murni, terdapat ukir-ukiran dengan motif ornamen berwarna emas, di bagian tengah pintu terdapat kaca beningyang di dalamnya terdapat gambar orang laki-laki dan perempuan, gambar tersebut seakan-akan terlihat menjadi wujud orang sungguhan, jika pintu ditutup bagaikan pengantin yang dipertemukan, jika pintu dibuka bagaikanpengantin yang dipisahkan,di sebelah kanan dan kiri pintu terdapat patung gupalayang terbuat dari batu diukir berbentuk raksasa, rambutgimbal terbuat dari kawat tembaga,mata lebar dan merah menyala, gigi terbuat dari perak, lidah terbuat dari tembaga berwarna emas kemerah-merahan, tangan kanan memegang senjata gada, tangan kiri memegang perisai,lubang bagian telinga dibuat tembus sampai hidung,di dalam kedua lubang hidung untuk rumah kumbang yang terdiri dari kumbang jantan dan betina, apabila pintu terbuka dan tiba-tiba pintu tertutup, kumbang tersebut seketika berbunyi dan terbang keluar dari lubang hidung, patung gupala terkesan hidup dan dapat bersuara hendak memangsa yang berada di sekitarnya. Diceritakan sang raja melangkah kembali berjalan melewati pintu Danapratapa, kemudian melihat ketiga permaisuri Prabu Kresna yakni: Dewi Jembawati, Dewi Rukmini, dan Dewi Setyaboma berada di dalam dhatulaya. Ketika sudah mengetahui sang raja kondur ngedhaton, ketiganya menjemput dari panangkilan kemudian jengkeng dan bersujud mengusap kaki sang raja seolah-olah menghaturkan sembah, sang raja segera dihantar memasuki bangsal manis melaksanakan perjamuan, namun terlihat dari raut wajahnya seperti sedang menyimpan masalah, sang raja menolak ajakan ketiga permaisurinya, setelah sang raja menjelaskan, akhirnya ketiga permaisuri dapat menerimanya. Kemudian sang raja memasuki panti busana, iasegera melepas busana kerajaan ganti memakai busana yang serba putih, segeralah membawa dupa ratus yang sudah disiapkan oleh abdi keraton, terlihat dari kejauhan besarnya tempat pembakaran dupa di sanggar pamujan meninggalkan sisa hingga menumpuk sebesar kepala gajah, perlahan sang raja memasuki sanggar pamujan, kemudian memulai bersamadi memohon kepada Sang Hyang Widdi.'

Kedua kandha tersebut sudah mencakup prosesi dan adegan kondur ngedhaton yang telah terjadi. Dalam pakeliran gaya Yogyakarta versi Mudjanattistomo dkk. (1977), prosesi kondur ngedhaton dilanjutkan dengan adegan kondur ngedhaton. Adapun urutan peristiwanya sebagai berikut: prosesi saat sang raja dan seluruh tokoh yang hadir di pertemuan agung meninggalkan sitinggil binaturata hingga terjadi adegan di depan gapura Danapratapa antara sang raja, permaisurinya, dan ditemani oleh emban. Iringan gending Ayak-ayak Laras sléndro pathet nem disuwuk dilanjutkan dengan Suluk Plencung Jugag atau Suluk Lagon Jugag laras sléndro pathet nem. Selesai suluk dilanjutkan dengan dialog antara sang raja dengan permaisuri. Hal yang dibahas biasanya tentang pokok masalah saat jejer I kemudian sang raja pamit hendak bersamadi di sanggar pamujan.

Kandha yang dibawakan $\mathrm{Ki}$ Timbul Hadiprayitno dalam Lakon Kalimasada sangat ringkas namun sudah mencakup prosesi kondur ngedhaton yang seharusnya dikelirkan. Adanya 
peristiwa limbukan juga mengurangi ruang waktu dalang untuk mendeskripsikan prosesi kondur ngedhaton. Adanya adegan limbukan ternyata mempengaruhi ruang waktu dalang untuk mengemas deskripsi kandha setelah prosesi kondur ngedhaton dan menghilangkan adegan kondur ngedhaton.

Pembahasan kandha selanjutnya adalah kandha menjelang jejer II. Kandha menjelang jejer II dilanjutkan dengan carita. Kandha jejer II Kahyangan Sapta Pratala versi Ki Timbul Hadiprayitno dalam Lakon Kalimasada dibawakan setelah peristiwa Pandhita Durna dan Patih Sengkuni mendatangi Prabu Baladewa. Dalang melantunkan Suluk Plencung Wetah laras sléndro pathet nem kemudian dilanjutkan pembawaan kandha carita. Berikut pemaparan kandha menjelang jejer II Kahyangan Sapta Pratala versi Ki Timbul Hadiprayitno dalam Lakon Kalimasada.

"Wauta, laaap wulung-wulung kéndhang, peksi mabur katrajang, alas rungkut karungkat awit perbawaning bandayuda sanggya para Kurawa mengsah Dyan Harya Setyaki. Dupi Radén Sadéwa dén prepegi déning Prabu Baladéwa dipun paringi priksa kathah-kathah satemah Radén Sadéwa mundur saking Nagari Ngastina, sinengka tindaknya daya-daya dumugi Negari Ngamarta sedya ngaturaken purwa madya wasana dénnya kautus gagar wigar tanpa karya. Sapengkernya Raden Sadéwa, Pandhita Durna nglajengaken kesagahanira dénnya badhe pados sraya budidaya sirnaning Pandhawa. Wauta, lamun kacandra tindaknya Sang Pandhita Durna luwar tan wekasan pindha wileding tirta saking pucaking haldaka". (Hadiprayitno, Lakon Kalimasada, MP3 No.04: menit ke 06.5308.01)

('Laaaap [gambaran sesuatu yang telah berlalu dengan cepat], banyak burung alap-alap [wulung-wulung] berterbangan, burung-burung kecil berhamburan di angkasa menjadi sasaran mangsanya, pepohonan di dalam hutan roboh tumbang karena ulah prajurit Kurawa yang telah berperang melawan Raden Setyaki. Saat Raden Sadewa dihadang oleh Prabu Baladewa dan dinasehatinya, seke- tika Raden Sadewa meninggalkan Negara Ngastina menuju Negara Ngamarta untuk menyampaikan bahwa usahanya gagal. Setelah Raden Sadewa meninggalkan Negara Ngastina, Pandhita Durna segera melanjutkan kesanggupannya untuk mencari sarana membunuh para Pandhawa. Diceritakan kepergian Pandhita Durna begitu cepat dan tanpa jejak bagaikan air yang jatuh dari puncak gunung.')

Kandha jejer II Kahyangan Sapta Pratala versi Ki Timbul Hadiprayitno dalam Lakon Kalimasada pada kalimat bagian awal memakai beberapa kata yang terdapat dalam kandha versi Mudjanattistomo dkk. (1977). Kalimat selanjutnya merupakan penambahan hasil improvisasi $\mathrm{Ki}$ Timbul Hadiprayitno sesuai dengan alur cerita dalam lakon tersebut.

Kandha menjelang adegan gara-gara biasanya juga dilanjutkan dengan carita. Pembawaan kandha menjelang adegan gara-gara terjadi setelah adegan perang gagal. Dalang melantunkan Suluk Lagon Wetah laras sléndro pathet sanga kemudian dilanjutkan pembawaan kandha carita. Pada Lakon Kalimasada pembawaan kandha menjelang adegan gara-gara saat setelah peristiwa Bathari Durga mendatangi Naga Cundhila dan Pandhita Durna. Dalang melantunkan Suluk Lagon Wetah larassléndro pathet sanga kemudian dilanjutkan pembawaan kandha carita. Berikut kandha menjelang adegan gara-gara dalam Lakon Kalimasada.

"Lepas tindaknya Resi Kumbayana miwah Prabu Baginda Raja sedya nggayuh tumuruning nugraha, kepéngin mundhi jimat Kalimasada Pustaka Jamus awit sabdanipun Bathari Durga kedah minggah Kahyangan Jonggringsaloka, mila dèn awatawati déning Sang Hyang Naga Cundhila miwah Bathari Durga. Nalika semanten wanci surya wus sanjakala, tan pantara dangu konjeming pertiwi, dadi pratandha gumelaring jagad, telasing rina sedya gumanti ratri, tan pantara dangu Hyang Candra mijil sedya mrebawani jagad raya, lumampahing Sang Hyang Candra panjer ing akasa wus dumugi titi wanci, wanciné wus ngancik gara-gara." (Hadiprayitno, Lakon Kalimasada, MP3 No.05: menit ke $14.41-15.44)$ 
('Kepergian Resi Kumbayana beserta Prabu Baginda Raja hendak mencari anugrah turunnya wangsit [wahyu], berkeinginan mempunyai jimat Kalimasada Pustaka Jamus, sesuai saran Bathari Durga mereka berdua harus naik ke Kahyangan Jonggringsaloka, oleh karena itu kepergian mereka diawasi oleh Sang Hyang Naga Cundhila dan Bathari Durga. Saat itu matahari perlahan mulai tenggelam, sebagai pertanda di bumi bahwa siang sudah berganti malam, kemudian Sang Hyang Candra berganti muncul di angkasa menyinari bumi dan seisinya, sebagai pertanda waktunya sudah memasuki adegan gara-gara.')

Kandha menjelang adegan gara-gara dalam Lakon Kalimasada merupakan hasil improvisasi Ki Timbul Hadiprayitno sesuai dengan alur cerita. Mengingat jejer III Lakon Kalimasada tidak tampak, maka isi kandha tersebut mendeskripsikan peristiwa yang telah terjadi dalam adegan gladhagan.

Carita adalah wacana yang diucapkan dalang berupa deskripsi sebuah peristiwa yang sedang terjadi dan akan terjadi. Pembawaaan carita dalam pakeliran disertai tokoh wayang. Carita dapat disertai iringan gending dan dapat tanpa disertai iringan gending (Mudjanattistomo dkk., 1977: 14). Pembawaan carita dalam Lakon Kalimasada terjadi saat menjelang datangnya tamu dalam jejer, menjelang adegan paséban njawi, menjelang jejer II dan V, menjelang adegan gara-gara, serta pada setiap peristiwa yang akan terjadi secara tiba-tiba atau dadakan dalam setiap adegan. Pembawaan carita pada bagian-bagian tersebut diawali dengan kandha. Namun pembawaan carita dapat tanpa diawali dengan kandha, misalnya saat akan datangnya tamu dalam jejer serta akan terjadinya peristiwa yang bersifat dadakan. Pembawaan carita yang tanpa diawali dengan kanda biasanya untuk membangun greget sahut dalam setiap peristiwa yang terjadi dalam adegan. Carita dalam Lakon Kalimasada versi Ki Timbul Hadiprayitno yang dibicarakan berikut meliputi: carita menjelang datangnya tamu dalam jejer I, menjelang adegan paséban njawi, menjelang jejer II, dan menjelang adegan gara-gara.

Carita menjelang datangnya tamu dalam jejer I Lakon Kalimasada terjadi saat Raden Sadewa hendak datang di pasowanan agung negara Ngastina. Dalang melantunkan Suluk Dhendha laras sléndro pathet nem kemudian dilanjutkan pembawaan carita. Berikut carita menjelang datangnya tamu dalam jejer I Lakon Kalimasada.

"Sebet byar wauta, éca dènira imbal pangandika ginem raras ganda rasa, Naréndra Ngastina, Prabu Duryudana saha Pandhita Durna dèn midhangetaken sanggyaning para kadang sentana, ingkang kapenggalih Prabu Duryudana dènnya sedya nggayuh sirnaning Pandhawa dupi Pandhita Durna anyagahi budidaya sirnaning Pandhawa, Prabu Duryudana bombong raosing penggalih, dumugi semanten dènnya imbal pangandikan kaya kena cobaning bathara nglenggahi tri pandurat, tri telu pandurat pangandikan, tigang wanda dèrèng kawedhar ing lathi kesaru gègèring njaba, pyak ngarsa tangkep wuri, kaya negara kelebon kelebon parangmuka, ingkang dadosaken gègèr horeging sanggya para wadya ingkang mara sowan, utusan saking Nagari Ngamarta, warujuning Pandhawa, sowan wonten Nagari Ngastina, mancat sitinggil binaturata dadosaken horeg sanggya para wadya, hé kanca ana dhayoh, ana dhayoh, pyak pyak pyak." (Hadiprayitno, Lakon Kalimasada, MP3 No.05: menit ke 09.47 - 11.08)

('Sebet byar [gambaran sesuatu yang telah berlalu dengan cepat], diceritakan perbincangan antara sang raja Negara Ngastina dengan Pandhita Durna yang didengarkan oleh para kerabat Negara Ngastina yang hadir dalam pertemuan agung, yang dibahas adalah ambisi Prabu Duryudana untuk membunuh Pandhawa, dan Pandhita Durna bersedia membantunya dengan menyusun strategi. Perbincanggan terpotong, seolah-olah mereka menerima cobaan dari dewa atas niatnya yang buruk. Belum selesai pembicaraan, tiba-tiba terlihat ada keramaian di luar keraton, segera siap siaga mereka yang hadir dalam pertemuan, seperti ketika musuh memasuki Negara Ngastina, yang menjadi sebab paniknya 
prajurityang menghadiri pertemuan agung adalah utusan dari Negara Ngamarta, bungsu dari Pandhawa datang di Negara Ngastina, menaiki tangga menuju sitinggil binaturata membuat kaget dan panik para abdi keraton, hei kawan, ada tamu.. ada tamu, minggir.. minggir..')

Melihat pemaparan carita menjelang adanya tamu dalam jejer I Lakon Kalimasada dapat dikatakan carita tersebut merupakan hasil improvisasi Ki Timbul Hadiprayitno sesuai dengan alur cerita yang terjadi. Isi dari carita tersebut menceritakan panyandra suasana yang terjadi di pasowanan agung dan terkait tokoh Raden Sadewa yang akan datang sebagai tamu.

Carita menjelang adegan paséban njawi dibawakan setelah pembawaan kandha dan adegan kondur ngedhaton berakhir. Dalang kemudian membawakan kandha yang disambung dengan carita. Setelah adegan limbukan Lakon Kalimasada, dalang membawakan kandha dilanjutkan carita. Berikut carita menjelang adegan paséban njawi Lakon Kalimasada.

"Kacarita ing medal njawi, Patih Sengkuni hangawé sanggya para kadang Kurawa, pating bleber, pating blulu yèn cinandra yayah mina katempuhjala."(Hadiprayitno, Lakon Kalimasada, MP3 No.03: menit ke $08.38-08.48)$

('Diceritakan di alun-alun, Patih Sengkuni melambaikan tangan dengan maksud memanggil para prajurit Kurawa, mereka tunggang langgang segera menghadap Patih Sengkuni seperti segerombolan ikan yang hendak dijala.')

Melihat carita menjelang adegan paséban njawi Lakon Kalimasada dapat dikatakan dibawakan secara singkat. Isi dalam carita tersebut menggambarkan prajurit Kurawa yang berlarian tunggang langgang menghadap Patih Sengkuni.

Carita menjelang jejer II dibawakan setelah pembawaan kandha. Carita jejer II Kahyangan Sapta Pratala versi Ki Timbul Hadiprayitno dalam Lakon Kalimasada dibawakan setelah peristiwa Pandhita Durna dan Patih Sengkuni mendatangi Prabu Baladewa. Dalang melantunkan Suluk Plencung Wetah laras sléndro pathet nem kemudian dilanjutkan pembawaan kandha carita. Berikut carita menjelang jejer II Kahyangan Sapta Pratala versi Ki Timbul Hadiprayitno dalam Lakon Kalimasada.

"Sinigeg gantya kang winursita, nahan ingkang wonten madyaning marga. Kang kinaryasambetingcaritanenggih Kahyangan Sapta Pratala, kang samya mara sowan ketingal dènnya gegandhèngan kunca." (Hadiprayitno, Lakon Kalimasada, MP3 No.04: menit ke 08.02 - 08.22)

(Tak diceritakan lagi mereka yang berada di tengah jalan. Diceritakan peristiwa di Kahyangan Sapta Pratala, mereka yang hendak hadir di pasowanan tampak bersama-sama/gegandhèngan kunca=tanda seorang dalang meminta iringan gending Gendhing Bondhèt laras sléndro pathet nem.')

Carita menjelang jejer II Kahyangan Sapta Pratala versi Ki Timbul Hadiprayitno dalam Lakon Kalimasadadapat dikatakan cukup singkat. Carita tersebut sebagai deskripsi penghantar cerita menuju adegan jejer atau babak selanjutnya, yaitu terjadi di Kahyangan Sapta Pratala. Sesuai sasmita iringan gending, adegan Kahyangan Sapta Pratala menggunakan iringan gending Gendhing Bondhèt laras sléndro pathet nem.

Carita menjelang adegan gara-gara dibawakan setelah pembawaan kandha. Carita adegan garagara versi Ki Timbul Hadiprayitno dalam Lakon Kalimasada dibawakan setelah pembawaan kandha yang menceritakan rangkaian peristiwa dalam adegan gladhagan selesai. Dalang melantunkan Suluk Lagon Wetah laras sléndro pathet sanga kemudian membawakan kandha. Usai membawakan kandha, dalang melantunkan Suluk Ada-ada Wetah Ngelik laras sléndro pathet sanga dilanjutkan dengan pembawaan carita menjelang adegan gara-gara. Berikut carita menjelang adegan gara-gara versi Ki Timbul Hadiprayitno dalam Lakon Kalimasada.

Carita menjelang adegan gara-gara Lakon Kalimasada versi Ki Timbul Hadiprayitno yang menceritakan bencana alam yang sudah reda karena pertolongan Sang Hyang Jagad Giri Nata dengan meneteskan Tirta Panjuta Nirmala dilanjutkan dengan cerita munculnya punakawan, dapat dikatakan singkat. Dapat dikatakan cukup singkat karena Ki Timbul Hadiprayitno dalam Lakon 


\section{Sembadra Ratu lebih panjang dalam membawakan Timbul Hadiprayitno dalam Lakon Kalimasada dan carita. Carita menjelang adegan gara-gara versi Ki Lakon Sembadra Ratu dilihat pada tabel 6.}

Tabel 6. Carita adegan gara-gara versi Ki Timbul Hadiprayitno dalam Lakon Kalimasada dan Lakon Sembadra Ratu.

\section{Lakon Kalimasada}

\section{Lakon Sembadra Ratu}

\begin{abstract}
"Saya banter sumuking gara-gara, sumundhul Kahyangan Jonggringsaloka, Sang Hyang Jagad Giripati gya ngasta cupumanik isi tirta panjuta nirmala katètèsaken jagad raya sirep sanalika ponang gara-gara, sireping gara-gara gumelaring jagad tata tentrem gemah ripah loh jinawi, kabarung swara jumeglug munggwing telenging samodra, sejatiné alon banter ngurmati wijiling Kyai Lurah Semar miwah putra cacah tiga, Ki Lurah Garèng, Pétruk, sumawana Bagong, pacak gegujengan ana madyaning ara-ara amba hakarya suka gumbiraning panggalih sanggya para sutresna, lumampahnya Ki Lurah Petruk satemah nelasak pategalan." (Hadiprayitno, Lakon Kalimasada, MP3 No.05: menit ke 16.43 - 17.36)

Terjemahan:

'Semakin mengerikan pengaruh dari gara-gara, hawa panas semakin ke atas hingga Kahyangan Jonggringsaloka, Sang Hyang Jagad Giripati segera membawa Cupu Manik berisikan Tirta Panjuta Nirmala, diteteskan di bumiseketika reda gara-gara yang terjadi, berakhirnya gara-gara bumi kembali aman tentram gemah ripah loh jinawi, disertai suara gemuruh dari dalam samudera, namun suara tersebut justru sebagai tanda untuk menghormati munculnya Kyai Lurah Semar dan ketiga anaknya, Ki Lurah Garèng, Pétruk, dan Bagong, mereka bersiap memberikan hiburan di tengah padang rumput yang luas dengan tujuan membuat senang segenap para hadirin yang menyaksikan, munculnya Ki Lurah Petruk lalu melewati semak-semak di ladang/ nelasak pategalan = tanda seorang dalang meminta iringan gending Playon Banyumasan laras sléndro pathet sanga.'
\end{abstract}

"Gara-gara, pratandhané jagad gara-gara, bumi gonjang-ganjing, langit kelap-kelap, kaya tangkep-tangkepa bumi langit, lemah bengkah bledug mangampak-ampak, lebu katyuping angin, ana lindhu sedina kaping pitu, horeging bumi akèh gunung kang longsor jugrug, musthikaning Gunung Jamurdipa moyag-mayig kaya njomplang-njomplanga, saka banter horeging bumi tirta samodralaya ngombak-ombak sedya ngelem dharatan, panas prabawanira mahanani mina kang gedhé nglumba kang cilik dadi lendhut blegedaba saka bantering ombak tirta samodralaya, dirgantara gya peteng ndhedhet lelimengan kaya bangun kasaput lebu, satemah ketiga dawa, udan barat salah mangsa dres awor lésus, lidhah thathit pating kalawèr, téja mangkara-kara, kluwung pating palengkung claratan pating calorot swaring yumantara gumaludhug nggoregaké jagad, saka bantering gara-gara sumundhul Kahyangan Jonggringsaloka, kaya bojat-bojata sela kori Séla Matangkep, kaya njomplang-njomplanga umpak Balé Marcukundhamanik, mèncèng wot ogal-agil pindha kinebur Kawah Candradimuka clak-kinoclak gambiralaya, dadi lendhut blegedaba ndadèkaké gègèr para widadarawidadari hapsara-hapsari bathara-bathari, gègèr pepuyengan para jawata, kabalasah klangenanira Hyang Jagad Nata kayu andhong, kayu muré, nyarengat sunguning lembu andini, ngakak tutuké Hyang Anantaboga, muntir kaya pecut penjalin tingal pucuké pethit Hyang Anantaboga, saka bantering gara-gara sumundhul Kahyangan Ondar-andir Bawana, kacarita Sang Hyang Pada sigra damel tentreming bawana, sigra ngasta Cupu Manik Asta Gina isi Tirta Kamandanu katamakaken jagad ingkang ketaman garagara, sirep sanalika gumelaring jagad, sirnaning gara-gara, gumelaring jagad tata tentrem gemah ripah loh jinawi, pranyata sampun ngantos kejot kalamun bawana wonten gara-gara, sayekti iku dadi gegalenganing lelakon, pratandha jagad sedya gantos alam saha jaman, nadyan gara-gara kang dumadi ana madyaning jagad pakeliran, kinarya ngurmati wijilira Ki Lurah Badranaya, Semar dalasan putra cacah tetiga ingkang sami pacak gegujengan ing madyaning ara-ara amba, alon aririh." (Hadiprayitno, Lakon Kalimasada, MP3 No.08: menit ke 09.54 - 12.10)

Terjemahan:

'Gara-gara, tanda bumi yang dilanda gara-gara adalah terjadinya bencana alam, bumi berguncang dengan dahsyat, sering muncul kilat di langit, bumi dan langit seakan-akan hampir menjadi satu, tanah terbelah asap menggumpal, debu berterbangan terbawa angin, sehari terjadi gempa bumi sebanyak tujuh kali, guncangan bumi membuat gunung dan deretan pegunungan longsor, puncak Gunung Jamurdipa terombang-ambing seperti hendak runtuh, dahsyatnya guncangan bumi juga membuat air samudera meluap ke daratan, hawa panas terasa hingga dasar lautan hingga membuat ikan-ikan besar melompat hingga permukaan laut, sedangkan ikan-ikan kecil musnah karena hanyut terbawa arus air laut yang meluap dengan deras, angkasa terlihat gelap gulita seperti saat fajar tertutup kabut tebal, sehingga terjadi kemarau panjang, hujan deras disertai angin lesus datang tidak pada musimnya, kilat dan petir menyambar berkali-kali, hingga muncul cahaya yang memancar, banyak pelangi bermunculan diiringi suara guntur semakin mengguncang dan menggetarkan bumi seisinya, dahsyatnya gara-gara menimbulkan hawa panas hingga Kahyangan Jonggringsaloka, menjadikan pintu séla matangkep lepas dari kerangkanya, penyangga tiang Balé Marcukundhamanik seperti akan runtuh, bergeser pindah posisi wot ogal-agil, Kawah Candradimuka meluap hingga lahar panas keluar mengalir membakar segalanya yang berada di sekitar Kawah Candradimuka hingga musnah membuat para dewa-dewi kebingungan, barang kesayangan Sang Hyang Jagad Nata berupa kayu andhong dan kayu muré musnah, tanduk Lembu Andini bertambah panjang dan tajam, mulut Sang Hyang Anantaboga menganga dan ekornya terjalin bagaikan ujung cambuk yang terbuat dari rotan. Dahsyatnya gara-gara terasa hingga Kahyangan Ondar-andir Bawana,diceritakan Sang Hyang Pada segera meredakan gara-gara yang telah melanda bumi, Ia segera membawa Cupu Manik Asta Gina yang berisi Tirta Kamandanu, diteteskan di bumiseketika reda gara-gara yang terjadi, hilangnya gara-gara menjadikan bumi kembali aman tentram gemah ripah loh jinawi, diharapkan tidak khawatir dan panik apabila bumi terjadi gara-gara, sesungguhnya hanya menjadi gejolak alam, menandakan bumi akan ganti alam dan jaman. Tetapi gara-gara yang terjadi di pakeliran sebagai tanda untuk menghormati munculnya Kyai Lurah Semar dan ketiga anaknya yang sudah bersiap bersiap memberikan hiburan di padang rumput yang luas, perlahan-lahan mereka muncul/ alon aririh = tanda seorang dalang meminta iringan gending Ayak-ayak Jalumampang laras sléndro pathet sanga.' 
Isi carita menjelang adegan gara-gara pada Lakon Sembadra Ratu versi Ki Timbul Hadiprayitno dapat dikatakan sangat lengkap. Ki Timbul mengembangkan carita tersebut dengan menambah banyak kosa kata sebagai panyandra adegan gara-gara. Banyaknya macam bencana alam yang terjadi dideskripsikan dalam carita tersebut. Sasmita iringan gending dalam carita adegan garagara Lakon Sembadra Ratu menandakan iringan gending yang digunakan untuk adegan gara-gara adalah Ayak-ayak Jalumampang laras sléndro pathet sanga.

Pocapan adalah dialog dalam pakeliran gaya Yogyakarta yang terjadi pada tokoh boneka wayang. Dalam pakeliran,pocapan dapat berupa monolog (satu tokoh boneka wayang yang berbicara sendiri mengungkapkan keadaan dirinya dari situasi yang dihadapi) atau dialog ( percakapan antar tokoh boneka wayang bisa dua tokoh atau lebih). Pocapan oleh dalang terjadi tanpa iringan gending namun dapat juga digunakan dalam iringan gending yang disirep. Pembawaan pocapan disertai dhodhogan sesuai kebutuhan dalam pakeliran (Mudjanattistomo dkk., 1977: 52-71).

Memahami karakter pocapan Ki Timbul Hadiprayitno dalam Lakon Kalimasada, kiranya dapat dikatakan pocapannya bersifat greget (dialog/ monolog terkesan seperti nyata benar-benar terjadi), cetha (jelas dalam pembawaan pengucapannya), kedal (suara antar tokoh boneka wayang dapat dibedakan sesuai karakter dan sifatnya), nges lan langut (mampu menarik hati yang menyaksikan saat dalang membangun suasana senang, lucu, sedih, prihatin, duka, dan lainnya), cucut (pandai menyisipkan humor dalam pocapan), dan gecul (humor yang dibawakannya tidak jorok atau mengarah ke porno). Bahasa yang digunakan dalam pocapan adalah bahasa pedalangan. Ki Timbul Hadiprayitno juga termasuk seorang dalang yang marsudi basa (pandai menggunakan bahasa sesuai aturan atau kaidah dalam sastra jawa), parama ing basa (pandai menggunakan macam-macam bahasa pedalangan secara merata sesuai kebutuhan dalam cerita yang terdiri dari: bahasa jawa krama inggil, bahasa jawa krama madya, bahasa jawa ngoko, bahasa kawi, dan bahasa bagongan), parama ing kawi (pandai menggunakan bahasa kawi), kawiradya (pandai mendeskripsikan suasana atau keadaan yang telah, sedang, dan akan terjadi melalui janturan, kandha, carita, dan pocapan, sehingga imajinasi pendengar atau penonton seolah-olah dapat terbawa dalam pementasannya). Berikut contoh pocapan versi Ki Timbul Hadiprayitno dalam Lakon Kalimasada yang menunjukan seorang dalang yang marsudi basa, parama ing basa, parama ing kawi, dan kawiradya.

Baladewa : "Yayi, kadang kula Pandhawa kalenggahan menika makarti menapa, teka saged ndadosaken sungkawaning penggalih yayi prabu?"

Duryudana: "Kaka prabu, ri paduka prelu caos priksa. Warsa ingkang sampun kepengker kadang Pandhawa kadhawuhan babat Wana Mrentani déning rama Prabu Dhestharastra. Keparengipun rama prabu badhe kaparingan Nagari Ngastina, nanging sampun ngantos Ngastina menika gempil dipun réka daya déning Paman Sengkuni tuwin Bapa Durna. Pandhawa kula dhawuhi babat Wana Mrentani, pangangkahipun Pandhawa wau mlebet Wana Mrentani kedah pejah dipun badhog déning sato galak tuwin dhedhemit Wana Mrentani. Namung para Pandhawa boten babak boten bucik, malah saya mencorong téjanipun. Wana Mrentani samenika dados negari, kasebat Nagari Ngamarta, Kasatriyan Jodhipati, Madukara, Bumi Retalun, Sawojajar. Dèrèng dangu anggènipun madeg nagari, parandéné raja manca negari kathah ingkang sami sumuyud wonten ing Nagari Ngamarta. Kalenggahan menika saya santosa, saya kuwawi para kadang Pandhawa.

Baladewa : "Inggih, lajeng?"

Duryudana: "Nalika dinten kepengker, yayi Prabu Anom Puntadéwa utusan gandhèk sakembaran ngaturaken nawala. Suraosing nawala, yayi Prabu Anom Puntadéwa kalenggahan menika badhé jumeneng nata wonten Nagari Ngamarta. Ingkang rayi Ngastina dipun suwun supados tedhak wonten Nagari Ngamarta ngawuningani jumenengipun Puntadéwa. Kepara 
kula dipun suwun supados medhar sabda. Pangandikanipun ingkang rayi Duryudana badhé kinarya paugeraning lampah Puntadéwa anggenipun ngayomi para kawula Nagari Ngamarta. Kaka prabu, rèhné Pandhawa menika saged kula sebat klilip utawi mengsah, tunggak kemadhuh, satru. Tunggak kemadhuh menika dipun celakana malah saya mbebayani jalaran mawa wisa. Nanging panyuwunipun Pandhawa mekaten wau, kula kedah kados pundi? Kula menapa kedah dumugi Nagari Ngamarta minangkani panuwunipun Pandhawa? Menapa inggih kula kèndelaken kémawon panyuwunipun Pandhawa? Menapa inggih kedah kula bangkaraken sedyaning Pandhawa sampun ngantos kalampah Pandhawa reraton ing Nagari Ngamarta."

Baladewa : "Jagad déwa bathara, kadang kula yayi.Sadèrèngipun kula matur wonten ngarsanipun yayi prabu, keparenga kula badhé matur langkung rumiyin. Lambaraning atur kula menika boten wonten raos emban cindhé emban siladan, awit Pandhawa menika adhi kula, Kurawa kadang kula enèm. Yèn Pandhawa Kurawa menika crah lajeng damel dredah, menika préhatos manah kula. Menawi Pandahwa badhé jumeneng nata wonten Nagari Ngamarta nyuwun rilaning penggalih yayi Prabu Duryudana, nyuwun yayi prabu supados tedhak wonten ing Ngamarta, menika tegesipun Pandhawa taksih ngaji-aji dhateng yayi Prabu Duryudana. Bilih kepareng ndhahar atur kula, keparenga yayi rawuh dhateng Nagari Ngamarta. Bilih yayi boten kedugi medhar sabda boten menapa-menapa, nanging waton yayi prabu rawuh wonten Nagari Ngamarta sampun saged dados sarana nyupeketaken kekadangan antawisipun Pandhawa tuwin Kurawa. Menawi yayi prabu kawratan rawuh dhateng Ngamarta upaminipun, keparenga utusan kéwala salah satunggaling kadang sentana ingkang pinitados dados badal wakilipun yayi prabu, dipun paringana nawala pertandha menika badal wakiling yayi prabu. mBok menawi menika saged dados sarana nyupeketaken kekadanganipun Pandhawa Kurawa, nanging bilih yayi prabu malah nyepèlekaken dhateng Pandhawa, langkung-langkung yayi kagungan kersa badhe mbangkaraken pikajenganing Pandhawa, wah menika klentu sanget yayi. Namung bilih yayi boten kepareng ndhahar atur kula, yayi badhé lekas kados pundi tumindak kados pundi mangga, nanging kula tunggak waru boten melu-melu."

Duryudana: "Enggèh. Paman Harya?"

Sengkuni : "Kula wonten dhawuh?"

Duyudana : "Kados pundi pamanggih pakenira paman?"

Sengkuni : "Bilih panjenengan dalem mundhut wawasan ingkang bapa kepatihan, badhéa dipun rengga-rengga ukara tuwin dipun prada mawi basa, yèn Pandhawa kaliyan Kurawa menika sejatosipun njih pancèn mengsah. Kadang menika rak namung tata gelar, nanging kasunyatan pamanggihipun boten cocog. Nggèr, tunggak kemadhuh menika menawi dipun dicaketi nggih mawa wisa, bilih panjenengan dalem nyuwun wawasan ingkang bapa kepatihan, samenika dipun tempukaken kaliyan kakang Durna. Jalaran Pandhawa saged babat Wana Mrentani menika iguhipun kakang Durna, senadyan kakang Durna menika natkala semanten sedyanipun nglorobaken, nanging kasunyatanipun kok Pandhawa malah manggih begja. Sinten ngertos menawi sejatosipun kakang Durna menika tata gelar wonten Ngastina ning batosipun wonten Pandhawa. Awit salembut-lembutipun banyu menika taksih lembut atining uwong. Yèn kakang Durna menika saèstu ngayomi Kurawa kedah kersa lan saged mbudidaya sirnaning Pandhawa. 
Yèn kakang Durna boten kersa mbudidaya sirnaning Pandhawa dipun cuthat saking kalanganing Kurawa. Ngastina boten mawi Durna boten napa-napa, Ngastina boten nganggo Durna dadi kok." (Hadiprayitno, Lakon Kalimasada, MP3 No.01 dan 02: menit ke 42.39 - 47.29 dan 00.00 $-04.00)$

\section{Terjemahan}

Baladewa : 'Yayi, kerabat saya Pandhawa saat ini sedang mempunyai hajat apa, kok bisa membuat kebimbangan dan khawatiran yayi prabu?'

Duryudana: 'Kaka prabu, paduka perlu mengetahuinya. Setahun silam kerabat Pan dhawa diutus oleh Rama Prabu Dhestharastra untuk menebangi pepohonan dan membersihkan isi $\mathrm{Hu}-$ tan Mrentani. Atas ijin Rama Prabu akan diberi wilayah Negara Ngastina, tetapi jangan sampai wilayah Negara Ngastina berkurang sedikitpun kemudian diliciki oleh Paman Sengkuni tuwin Bapa Durna. Saya mengutus kerabat Pandhawa untuk menebangi pepohonan dan membersihkan isi Hutan Mrentani, dengan tujuan kerabat Pandhawa dapat mati dimangsa oleh hewan buas dan setan-setan penunggu Hutan Mrentani.Tetapi para Pandhawa tidak terluka sama sekali, malah sampai saat ini semakin hebat. Hutan Mrentani sekarang sudah menjadi sebuah negara bernama Negara Ngamarta, di dalamnnya terdapat banyak kasatriyan antara lain: Kasatriyan Jodhipati, Madukara, Bumi Retalun, dan Sawojajar. Belum lama menjadi sebuah negara sampai saat ini sudah banyak para raja dari berbagai kerajaan yang datang bersekutu dengan Nagari Ngamarta. Sampai waktu ini para Pandhawa semakin kuat dan abadi.'

Baladewa : "Iya, lalu?"

Duryudana: 'Beberapa hari yang lalu, Yayi Prabu Anom Puntadéwa mengutus ab- dinya memberikan sepucuk surat. Isi surat tersebut adalah yayi Prabu Anom Puntadéwa saat ini hendak dinobatkan menjadi raja di Negara Ngamarta. Saya diminta untuk hadir di Negara Ngamarta menjadi saksi penobatannya. Kemudian saya diharapkan untuk memberi petuah-petuah sebagai pedoman laku Puntadéwa dalam mengayomi rakyat Negara Ngamarta. Kaka prabu, karenasaya menganggap Pandhawa adalah musuh atau tunggak kemadhuh. Tunggak kemadhuh itu jika kita mendekati maka akan celaka karena beracun dan berbisa.Namun menanggapi undangan dari kerabat Pandhawa tersebut saya harus bagaimana? Apakah saya harus datang di Negara Ngamarta memenuhi undangan Pandhawa? Apakah saya diamkan saja? Atau acara tersebut saya gagalkan, jangan sampai terlaksana Pandhawa menguasai Negara Ngamarta.'

Baladewa : "Jagad déwa bathara, saudaraku yayi. Sebelum saya menyampaikan tanggapan kepada yayi prabu, perkenankanlah saya memulai pembicaraan terlebih dahulu. Dasar tanggapan saya inisama sekali tidak ada rasa pilih kasih, karena Pandhawa saya anggap sebagai adik, sedangkan Kurawa sebagai saudara muda. Kalau Pandhawa dan Kurawa berselisih hingga terjadi perpecahan, saya justru prihatin. Apabila Pandhwa akan melaksanakan penobatan raja di Negra Ngamarta kemudian meminta kesediaan yayi Prabu Duryudana untuk hadir di Negara Ngamarta itu adalah sebuah kehormatan bagi yayi Prabu Duryudana.Saran saya, sebaiknya yayi prabu hadir di Negara Ngamarta sebagai sara silaturahmi antara kerabat Kurawa dan Pandhawa. Apabila yayi prabu keberatan untuk menghadiri tidak menjadi masalah, sebaiknya ada wakil yang mengganti kehadiran yayi prabu.Namun apabila 
yayi prabu menyepelekan Pandhawa, terlebih mempunyai niat untuk menggagalkan acara tersebut, wah hal tersebut sangat salah, yayi. Jika tanggapan saya ini tidak diterima sam sekali, bagaimanapun saya tidak akan ikut campur dalam masalah tersebut.'

Duryudana: 'Iya. Paman Harya?'

Sengkuni : 'Saya. Ada perintah?'

Duyudana : 'Bagaimana tanggapan paman?'

Sengkuni : 'Apabila paduka menanyakan tanggapan dari bapa kepatihan, bagaimanapun jika dilebih-lebihkan dengan kata-kata dan diperindah dengan bahasa, sesungguhnya Pandhawa dan Kurawa adalah musuh.Saudara itu hanya tampak secara kasat mata, namun kenyataannya tidak sependapat. Nggèr, tunggak kemadhuh itu apabila didekati berbahaya, jika paduka meminta tanggapan dari bapa kepatihan, sekarang dipertanyakan saja kepada kakang Durna. Karena Pandhawa berhasil menebangi pepohonan dan membersihkan isi Hutan Mrentani adalah saran kakang Durna, walaupun niat kakang Durna saat itu menjerumuskan, namun kenyataannya malah berhasil dan beruntung. Barangkali kakang Durna tampak secara lahir berada di Ngastina namun batinnya membela Pandhawa. Karena selembut-lembutnya air masih lembut batin perasaan manusia. Jika kakang Durna benar-benar bisa mengayomi Kurawa seharusnya sanggup menyusun strategi untuk membunuh Pandhawa. Apabila kakang Durna tidak sanggup, dikeluarkan saja dari kalangan Kurawa. Ngastina tanpa Durna tidak masalah, Ngastina tanpa Durna juga masih bisa berdiri kok.'

Melihat dari sepotong pocapan dalam adegan jejer I Lakon Kalimasada, dapat dikatakan bahwa beliau memiliki banyak perbendaharaan kata. Pocapan di atas mempunyai inti pembicaraan bahwa Prabu Duryudana bimbang menanggapi surat dari Prabu Anom Puntadéwa untuk menghadiri acara penobatan Prabu Anom Puntadéwa sebagai raja di Negara Ngamarta. Pocapan antara Prabu Duryudana, Prabu Baladewa, dan Patih Sengkuni terkesan hidup masing-masing karakternya. Tampak dilihat melalui pocapan tersebut karakter setiap tokoh muncul. Prabu Duryudana tampak berkarakter seorang raja yang tidak mempunyai pendirian, Prabu Baladewa tampak berkarakter seorang raja yang mempunyain pemikiran bijaksana, sedangkan Patih Sengkuni tampak mempunyai karakter seorang patih yang licik dan senang mengadu domba. Melihat contoh pocapan di atas baik dalam pembawaan dan kosa kata bahasa yang digunakan dapat dikatakan Ki Timbul memenuhi kriteria-kriteria yang sudah disebutkan di awal. Hal tersebut kiranya erat hubungannya dengan apa yang dikatakan oleh Ki Margiyana (wawancara, 02 April 2016), bahwa sastra dan bahasa yang digunakan Ki Timbul Hadiprayitno saat pementasan memang banyak ngopèni sastra dan bahasa dari Ki Nartosabdo.

Pembahasan unsur gerak Lakon Kalimasada versi Ki Timbul Hadiprayitno tidak dilakukan karena keterbatasan data penelitian yang berbentuk rekaman audio. Dengan demikian penambahan, pengurangan, dan penggantian unsur gerak yang berkaitan dengan keahlian olah sabet Ki Timbul dalam bentuk visual tidak dapat ditampilkan.

\section{Penutup}

Struktur caking pakeliran Lakon Kalimasada versi Ki Timbul Hadiprayitno terjadi penambahan, pengurangan, serta penggantian pada setiap unsurnya. Meskipun ada penambahan, pengurangan, dan penggantian yang dilakukan oleh $\mathrm{Ki}$ Timbul, tetapi Lakon Kalimasada masih dapat dinikmati sebagai caking pakeliran gaya Yogyakarta. Unsur pengadegan Lakon Kalimasada versi $\mathrm{Ki}$ Timbul Hadiprayitno pada dasarnya terdapat tujuh adegan pokok yang berperan menjadi jejer. Setelah dilihat dari hasil analisis terjadi pengurangan jejer, pengurangan adegan kondur ngedhaton yang digedhong dalam bentuk kandha, penambahan peristiwa limbukan, penggantian jejer III, VI, dan VII menjadi gladhagan, dan penambahan adegan dalam wilayah pathet manyura. Sebagian besar unsur iringan dalam Lakon Kalimasada menggunakan iringan gending, 
Sulukan, keprakan, dan dhodhogan Lakon Kalimasada menggunakan iringan gending, sulukan, keprakan, dan dhodhogan gaya Yogyakarta. Pada adegan perang bégal dan setelah adegan pungkasan terdapat sedikit penggunaan iringan gending dan sulukan gaya Surakarta. Dalam unsur naratif Lakon Kalimasada tampak kekonsistenan dan keahlian bahasa satra Ki Timbul Hadiprayitno pada janturan, kandha, carita, dan pocapan. Sesuai dengan keterangan Kasidi, Udreka, dan Margiyana dapat disimpulkan bahwa keahlian tersebut didapat dengan cara menjadi abdi dalem Keraton Ngayogyakarta Hadiningrat, nyantrik dalang senior pada masanya, berdiskusi, membaca buku, serta mengidolakan Ki Nartosabdo hingga banyak ngopèni sastra dan bahasa dari Ki Nartosabdo. Unsur gerak dijelaskan dalam bentuk deskripsi sesuai perjalanan cerita dalam lakon tersebut berdasarkan tafsir penulis sebagai pelaku, pengamat, dan penonton.

Lakon Kalimasada versi $\mathrm{Ki}$ Timbul Hadiprayitno secara struktur caking pakeliran mulai dipengaruhi oleh gaya Surakarta. Dalam caking pakeliran Lakon Kalimasada, Ki Timbul Hadiprayitno memasukkan adegan limbukan dalam pementasannya. Hal tersebut menunjukkan keterbukaan Ki Timbul Hadiprayitno mengikuti perkembangan jaman atau biasa disebut dengan istilah 'anut jaman kelakoné. Seperti yang dikatakan oleh Kasidi bahwa Ki Timbul termasuk dalang yang mempopulerkan limbukan pada tahun 1992-an dengan cak-cakan gaya Yogyakarta. Pergaulannya dengan para dalang lintas gaya pakeliran diduga kuat menjadi proses belajar Ki Timbul sebagai seniman dalang. Sehingga hasil dari proses tersebut dapat memberi warna baru dalam caking pakelirannya, hal ini dapat dilihat dalam Lakon Kalimasada versi Ki Timbul Hadiprayitno.

Caking pakeliran Lakon Kalimasada versi Ki Timbul Hadiprayitno memberikan warna tersendiri dalam kemasan pakeliran gaya Yogyakarta yang telah mengikuti perkembangan jaman tanpa merusak kaidah caking pakeliran gaya Yogyakarta yang sudah ada. Dapat dikatakan Ki Timbul Hadiprayitno yang dikenal sebagai dalang yang teguh mempertahankan pedalangan gaya Yogyakarta ternyata dalam perkembangan kariernya terbuka terhadap perubahan dan perkembangan jaman. Diharapkan penelitian ini memperkaya penelitian struktur caking pakeliran gaya Yogyakarta dalam ilmu pedalangan.

\section{Kepustakaan}

\section{a. Acuan}

Kasidi. 2000. "Pengembangan Struktur Pergelaran Wayang Gaya Yogyakarta Masa Kini. IDEA Jurnal Ilmiah Seni Pertunjukan, Edisi 1 no.7: 75-85. Yogyakarta: Tarawang Press. 2009. Suluk Wayang Kulit Purwa Gaya Yogyakarta. Yogyakarta: Bagaskara.

Mudjanattistomo, dkk. 1977. Pedhalangan Ngayogyakarta Jilid I. Yogyakarta: Yayasan Habirandha Keraton Ngayogyakarta Hadiningrat.

Nojowirongko, M. Ng.1954. Serat Tuntunan Padalangan Djilid I. Ngajogjakarta: Tjabang Bagian Bahasa Ngajogjakarta Djawatan Kebudajaan, Kementrian P. P. dan K.

Tim Penulis Sena Wangi. 1999. Ensiklopedi Wayang Indonesia, Jilid III. Jakarta: Penerbit Sena Wangi.

2016. Filsafat Wayang

Sistematis. Jakarta: Penerbit Sena Wangi.

\section{b. Audio-Visual}

Hadiprayitno, Timbul. tt. Lakon Kalimasada. (Rekaman Audio MP3)

Hadiprayitno, Timbul . tt. Lakon Wahyu Imandaya Nutuh. (Rekaman Audio MP3)

Hadiprayitno, Timbul. tt. Lakon Kuncaramanik. (Rekaman Audio MP3)

Hadiprayitno, Timbul. tt. Lakon Setya Wening. (Rekaman Audio MP3)

Hadiprayitno, Timbul.tt. Lakon Sembadra Ratu. (Rekaman Audio MP3)

\section{c. Narasumber}

Ki Kasidi Hadiprayitno. Umur: 59 tahun. Pekerjaan: Dosen Jurusan Pedalangan FSP ISI Yogyakarta sekaligus seniman dalang. Alamat: Patalan, Bantul, Yogyakarta.

Ki Cermagupita (Basiroen Hadisoemarto Alm.). Umur: 93 tahun. Pekerjaan: Seniman dalang Yogyakarta sekaligus mantan Tenaga Pengajar Luar Biasa Jurusan Pedalangan FSP ISI Yogyakarta. Alamat: Cokrodiningratan, Jetis, Yogyakarta. 
Ki Margiyana. Umur: 62 tahun. Pekerjaan: Seniman dalang sekaligus Tenaga Pengajar Luar Biasa Jurusan Pedalangan FSP ISI Yogyakarta. Alamat: Sewon, Bantul, Yogyakarta.
Ki Udreka. Umur: 50 tahun. Pekerjaan: Dosen Jurusan Pedalangan FSP ISI Yogyakarta sekaligus seniman dalang. Alamat: Imogiri, Bantul, Yogyakarta. 